\title{
Structural Characteristics of the Guaiacyl-Rich Lignins From Rice (Oryza sativa L.) Husks and Straw
}

\author{
Mario J. Rosado, Jorge Rencoret, Gisela Marques, Ana Gutiérrez and José C. del Río* \\ Department of Plant Biotechnology, Instituto de Recursos Naturales y Agrobiología de Sevilla, CSIC, Seville, Spain
}

\section{OPEN ACCESS}

Edited by:

Aymerick Eudes,

Lawrence Berkeley National Laboratory, United States

Reviewed by:

Noppadon Sathitsuksanoh, University of Louisville, United States

Kwang Ho Kim,

Korea Institute of Science and Technology (KIST), South Korea

*Correspondence: José C. del Río delrio@irnase.csic.es

Specialty section: This article was submitted to Plant Metabolism

and Chemodiversity,

a section of the journa

Frontiers in Plant Science

Received: 11 December 2020 Accepted: 26 January 2021

Published: 19 February 2021

Citation:

Rosado MJ, Rencoret J, Marques G, Gutiérrez $A$ and del Río JC (2021) Structural Characteristics of the Guaiacyl-Rich Lignins From Rice (Oryza sativa L.)

Husks and Straw.

Front. Plant Sci. 12:640475. doi: 10.3389/fpls.2021.640475
Rice (Oryza sativa L.) is a major cereal crop used for human nutrition worldwide. Harvesting and processing of rice generates huge amounts of lignocellulosic byproducts such as rice husks and straw, which present important lignin contents that can be used to produce chemicals and materials. In this work, the structural characteristics of the lignins from rice husks and straw have been studied in detail. For this, whole cell walls of rice husks and straw and their isolated lignin preparations were thoroughly analyzed by an array of analytical techniques, including pyrolysis coupled to gas chromatography-mass spectrometry (Py-GC/MS), nuclear magnetic resonance (NMR), and derivatization followed by reductive cleavage (DFRC). The analyses revealed that both lignins, particularly the lignin from rice husks, were highly enriched in guaiacyl (G) units, and depleted in p-hydroxyphenyl $(H)$ and syringyl $(S)$ units, with H:G:S compositions of 7:81:12 (for rice husks) and 5:71:24 (for rice straw). These compositions were reflected in the relative abundances of the different interunit linkages. Hence, the lignin from rice husks were depleted in $\beta-0-4^{\prime}$ alkyl-aryl ether units (representing 65\% of all inter-unit linkages), but presented important amounts of $\beta-5^{\prime}$ (phenylcoumarans, $23 \%)$ and other condensed units. On the other hand, the lignin from rice straw presented higher levels of $\beta-O-4^{\prime}$ alkyl-aryl ethers (78\%) but lower levels of phenylcoumarans ( $\beta$ $\left.5^{\prime}, 12 \%\right)$ and other condensed linkages, consistent with a lignin with a slightly higher $\mathrm{S} / \mathrm{G}$ ratio. In addition, both lignins were partially acylated at the $\gamma-\mathrm{OH}$ of the side-chain (ca. 10-12\% acylation degree) with $p$-coumarates, which overwhelmingly occurred over S-units. Finally, important amounts of the flavone tricin were also found incorporated into these lignins, being particularly abundant in the lignin of rice straw.

Keywords: grasses, lignin, $p$-coumarates, ferulates, tricin, sinapyl $p$-coumarates

\section{INTRODUCTION}

Lignin is a complex aromatic heteropolymer present in the cell-walls of vascular plants where it provides structural support, waterproofs the cell wall enabling transport of water and solutes through the vascular system, and acts as a barrier against pathogens. Unlike other natural biopolymers present in the plant cell wall (i.e., hemicelluloses, cellulose, proteins, etc.), that have a fixed and established structure, the structure of the lignin polymer lacks any regular order of repeating units and its composition widely fluctuate among taxa, from plant to plant, among different tissues of the same plant, and also with growing stage (Campbell and Sederoff, 1996; 
Donaldson, 2001; Vermerris and Boon, 2001; Rencoret et al., 2011; Lourenço et al., 2016). The high variability in lignin composition in plants is a consequence of the timing of the supply of the individual monomers to the lignifying zone and to the mechanism of lignin biosynthesis. Lignin is formed by the combinatorial oxidative radical coupling of three main monolignols, $p$-coumaryl, coniferyl, and sinapyl alcohols, that form the respective $p$-hydroxyphenyl $(H)$, guaiacyl $(G)$, and syringyl (S) lignin units when incorporated into the polymer, and this mechanism generates a series of substructures with a considerable variety of inter-unit linkages $\left(\beta-O-4^{\prime}, \beta-5^{\prime}, \beta-\right.$ $\beta^{\prime}, \beta-1^{\prime}, 5-5^{\prime}, 4-O-5^{\prime}$, etc.) within the polymer (Ralph et al., 2004; Vanholme et al., 2010, 2019). During the last few years, other phenolic compounds derived from beyond the canonical monolignol biosynthetic pathway have also been identified to behave as true lignin monomers participating in coupling and cross-coupling reactions with monolignols and being integrally incorporated into the lignin polymer (del Río et al., 2020). This is the case of the flavone tricin, that was found incorporated into the lignin structure in grasses and other monocots (del Río et al., 2012b; Rencoret et al., 2013; Lan et al., 2015, 2016a,b), or the hydroxystilbenes, particularly piceatannol, that were found incorporated into the lignins of palm fruit endocarps (del Río et al., 2017; Rencoret et al., 2018). The discoveries of these "novel" lignin monomers widely expanded our understanding of the lignin structure and revealed the structural complexity, heterogeneity, and variability of the lignin polymer.

Lignin is the only natural, high-molecular-weight polymer, with an aromatic backbone, making it an exceptional source for producing chemicals, biofuels, and materials that are currently obtained from fossil resources. Lignin is available in high amounts from lignocellulosic residues from the processing of agricultural or forest biomass. In this context, harvesting and processing of cereal crops, which are among the world's most cultivated staple food crops, generate vast amounts of lignocellulosic by-products that can be used as low cost feedstocks to obtain lignin. Among them, rice (Oryza sativa L.), a perennial monocotyledonous grass belonging to the Poaceae, is one of the most cultivated and consumed cereals in the world. In 2018 rice paddy accounted for up to 167 million cultivated ha. with a global rice production of 782 million Mt (FAOSTAT, 2020). Harvesting and processing of rice generates huge amounts of two main by-products, namely rice husks and rice straw. The global production of these by-products amounted up to approximately 156 million Mt of husks (Gao et al., 2018), and over 730 million Mt of rice straw (Swain et al., 2019). These by-products are usually used as fodder or burned for co-generation of heat and power with the subsequent environmental problems (Kumar et al., 2016). However, rice husks and straw are lignocellulosic materials with important amounts of carbohydrates and lignin, and because their relatively low price and high availability, they have been considered excellent feedstocks for the production of chemicals, biofuels and bio-based materials (Lu and Hsieh, 2012; Kalita et al., 2015; Abraham et al., 2016; Gou et al., 2018; Swain et al., 2019; Sharma et al., 2020; Bhattacharyya et al., 2020).

As the lignin composition varies among different tissues of the same plant, it is expected that the lignins from rice husks and straw may have different compositions, a feature that can hinder the development of efficient conversion technologies for these lignocellulosic materials. Therefore, is imperative to know in detail the composition and structure of the lignins of these lignocellulosic materials for their efficient utilization. There have been few studies describing the lignin extraction from rice husks and straw after acidic and/or basic pretreatments although with limited attention paid to their composition (Kumar et al., 2016, 2019; Dagnino et al., 2018; Yeframova et al., 2019). However, studies regarding the detailed composition and the structural characteristics of the native lignins in rice husks and straw have been comparatively scarce. A previous work on the lignin from rice husks indicated that it was mainly formed by $\mathrm{G}$ - and $\mathrm{H}$-lignin units, with minor amounts of S-units, and found evidences for $\beta$ O-4 alkyl-aryl ether, phenylcoumaran, and resinol substructures, but did not provide any additional structural information (Salanti et al., 2010). Other studies of the lignin in rice culms reported, besides the typical lignin inter-unit linkages $(\beta-O-4, \beta-5$, and $\beta$ $\beta$ ), the occurrence of $p$-coumaroylated lignin units and tricin (Lam et al., 2019; Takeda et al., 2019). In this article, we report the comprehensive structural characterization of the lignins of rice husks and straw by the use of different analytical techniques, including analytical pyrolysis coupled to gas chromatography and mass spectrometry (Py-GC/MS), two-dimensional nuclear magnetic resonance (2D-NMR), and the so-called derivatization followed by reductive cleavage (DFRC) degradation method. The lignin in the whole cell walls of rice husks and straw were first analyzed "in situ" by these analytical techniques, which provided information of the lignin characteristics without the need of their isolation, thus avoiding possible structural modifications during the isolation process. Then, for a more detailed structural characterization, the lignins from rice husks and straw were isolated by traditional procedures (Björkman, 1956), and subsequently analyzed by the same techniques. The results presented here will significantly improve our knowledge of the lignins from these important rice by-products that will help maximizing the industrial use of these materials, as well as providing important inputs for further bioengineering of cell wall lignin to improve the utilization of the rice biomass.

\section{MATERIALS AND METHODS}

\section{Rice Husks and Rice Straw Samples and Determination of Their Main Constituents}

Samples of rice (O. sativa L., var. Indica, Puntal) husks and straw were obtained from a paddy field located in Isla Mayor (Seville, South Spain). The samples were air-dried and knife-milled using an IKA knife mill (Janke \& Kunkel, Staufen, Germany) with $1 \mathrm{~mm}$ screen. The contents of extractives (acetone, methanol, and water-soluble extractives) were determined by successive extraction with acetone in a Soxhlet apparatus for $8 \mathrm{~h}$, then with methanol $(8 \mathrm{~h})$, and finally with distilled water $(8 \mathrm{~h})$. The extractives contents were then determined gravimetrically after evaporating the solvents in a rotary evaporator. Klason 
lignin content was estimated as the residue after sulfuric acid hydrolysis of the pre-extracted material according to Tappi test method T222 om-88 (Tappi Standard Test Methods 20042005, 2004). The Klason lignin content was then corrected for proteins, determined from the $\mathrm{N}$ content measured in a LECO CHNS-932 Elemental Analyzer (LECO Corp., St. Joseph Mich.) using a 6.25 factor (Darwill et al., 1980), and ash (determined as indicated below for the whole samples). The acid-soluble lignin was determined, after the insoluble lignin was filtered off, by UV-spectroscopy at $205 \mathrm{~nm}$ using $110 \mathrm{~L} \mathrm{~cm}^{-1} \mathrm{~g}^{-1}$ as extinction coefficient, according to Tappi method UM 250 (Tappi Standard Test Methods 2004-2005, 2004). The holocellulose (hemicelluloses and $\alpha$-cellulose) was isolated from the pre-extracted samples by delignification for $4 \mathrm{~h}$ using the acid chlorite method (Browning, 1967). The $\alpha$-cellulose content was determined by removing the hemicelluloses from the holocellulose by alkali extraction (Browning, 1967). Finally, the ash content was determined by heating the samples for $6 \mathrm{~h}$ at $575^{\circ} \mathrm{C}$ in a muffle furnace. Three replicates were used for each sample.

\section{Isolation of "Milled-Wood Lignins" From Rice Husks and Straw}

The "Milled-Wood Lignin" (MWL) preparations were isolated from rice husks and straw using the standard procedure (Björkman, 1956). Briefly, around $70 \mathrm{~g}$ of previously preextracted samples were finely milled using a Retsch PM100 planetary ball mill (Restch, Haan, Germany) for $5 \mathrm{~h}$ at $400 \mathrm{rpm}$ using a $500 \mathrm{~mL}$ agate jar and agate ball bearings $(20 \times 20 \mathrm{~mm})$. The milled samples were then extracted $(3 \times 12 \mathrm{~h})$ with dioxane-water $(90: 10, \mathrm{v} / \mathrm{v})(20 \mathrm{~mL}$ of solvent per gram of milled sample) and the isolated crude MWLs were subsequently purified as described elsewhere (del Río et al., 2012a). The isolated MWLs yields were $\sim 20 \%$ of the Klason lignin contents of the original material.

\section{Pyrolysis Coupled to Gas Chromatography and Mass Spectrometry}

Pyrolysis of the whole cell walls of rice husks and straw and of their isolated MWLs (ca. $1 \mathrm{mg}$ ) were performed at $500^{\circ} \mathrm{C}$ in an EGA/PY-3030D microfurnace pyrolyzer (Frontier Laboratories Ltd., Fukushima, Japan) connected to a GC 7820A (Agilent Technologies, Inc., Santa Clara, CA, United States) equipped with a DB-1701 fused-silica capillary column $(30 \mathrm{~m} \times 0.25 \mathrm{~mm}$ i.d., $0.25 \mu \mathrm{m}$ film thickness) and an Agilent 5975 mass-selective detector (EI at $70 \mathrm{EV}$ ). The oven temperature was programmed from $50^{\circ}$ to $100^{\circ} \mathrm{C}$ at $20^{\circ} \mathrm{C} \mathrm{min}^{-1}$ and then ramped to $280^{\circ} \mathrm{C}$ at a heating rate of $6^{\circ} \mathrm{C} \mathrm{min}^{-1}$ and held for $5 \mathrm{~min}$. The carrier

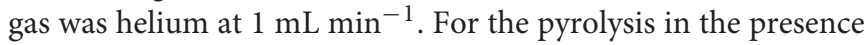
of tetramethylammonium hydroxide (TMAH), around $1 \mathrm{mg}$ of sample were mixed with $0.5 \mathrm{~mL}$ of TMAH $(25 \% \mathrm{w} / \mathrm{w}$, in methanol), and the pyrolysis was carried out as described above. The released compounds were identified by comparison of their mass spectra with those of the Wiley and NIST libraries, with those reported in the literature (Ralph and Hatfield, 1991), and when possible, by comparison with the retention times and mass spectra of our own collection of authentic standards. Molar peak areas were calculated for the released pyrolysis products, the summed areas were normalized, and the data for two repetitive analyses were averaged and expressed as percentages. The relative standard deviation for the pyrolysis data was below $10 \%$. No attempt was made to calculate the response factor for every single compound released. However, for most of the lignin-derived phenols, the response factors are quite similar (Bocchini et al., 1997), with the exception of vanillin, but this is a minor peak here.

\section{Two-Dimensional Nuclear Magnetic Resonance Spectroscopy}

Two-dimensional nuclear magnetic resonance (2D-NMR) spectra were recorded on an AVANCE III $500 \mathrm{MHz}$ instrument (Bruker, Karlsruhe, Germany) at the NMR facilities of the General Research Services of the University of Seville. For 2DNMR of the whole cell walls, around $60 \mathrm{mg}$ of finely ball-milled extractives-free samples were swollen in $0.6 \mathrm{~mL}$ of DMSO- $d_{6}$ according to the method previously described (Kim et al., 2008; Rencoret et al., 2009). In the case of the MWLs, around $40 \mathrm{mg}$ were dissolved in $0.5 \mathrm{~mL}$ of DMSO- $d_{6}$. Heteronuclear Single Quantum Coherence (HSQC) experiments used Bruker's standard "hsqcetgpsisp2.2" pulse program (adiabatic-pulsed version) using the parameters already described (del Río et al., $2012 \mathrm{~b})$. The central solvent peak was used as an internal reference $\left(\delta_{C} 39.5 ; \delta_{H} 2.49\right)$. Signal assignments were made by comparison with literature (del Río et al., 2008, 2012b; Ralph et al., 2009; Rencoret et al., 2018). A semi-quantitative analysis of the volume integrals of the HSQC cross-relation signals was performed using Bruker's Topspin 3.5 as previously described (del Río et al., 2012b). In the aliphatic oxygenated region, the relative abundances of side-chains involved in the various inter-unit linkages were estimated by integration of the areas of the $\mathrm{C}_{\alpha} / \mathrm{H}_{\alpha}$ correlations (signals $\mathrm{A}_{\alpha} / \mathrm{A}^{\prime}{ }_{\alpha}, \mathrm{B}_{\alpha}, \mathrm{C}_{\alpha}, \mathrm{C}_{\alpha}^{\prime}, \mathrm{D}_{\alpha}, \mathrm{F}_{\alpha}$ ). The relative abundances of cinnamyl alcohol end-groups (I) were determined by integration of the $\mathrm{C}_{\gamma} / \mathrm{H}_{\gamma}$ correlation signals $\left(\mathrm{I}_{\gamma}\right)$, whereas the abundance of cinnamaldehyde end-groups $(\mathrm{J})$ was determined by integrating the signal from the $\mathrm{C}_{8} / \mathrm{H}_{8}$ correlations $\left(\mathrm{J}_{8}\right)$ and comparing with that of $\mathrm{I}_{\beta}$. In the aromatic/unsaturated region, the signals used to quantitate the relative abundances of the aromatic units were $\mathrm{S}_{2,6}, \mathrm{G}_{2}, \mathrm{H}_{2,6}, \mathrm{~T}_{6}, \mathrm{FA}_{2}, p \mathrm{CA}_{2,6}$; as signals $\mathrm{S}_{2,6}, \mathrm{H}_{2,6}$, and $p \mathrm{CA}_{2,6}$ involve two proton-carbon pairs, their volume integrals were halved. The relative abundances of $p \mathrm{CA}$, $\mathrm{FA}$, and $\mathrm{T}$ were referred to as a percentage of the total lignin units $(S+G+H=100 \%)$.

\section{Derivatization Followed by Reductive Cleavage}

The derivatization followed by reductive cleavage (DFRC) was performed according to the originally developed method (Lu and Ralph, 1997a,b, 1998) and the detailed explanation of the experimental procedure can be found elsewhere (del Río et al., 2012a). Briefly, around $5 \mathrm{mg}$ of MWL were stirred for $2 \mathrm{~h}$ at $50^{\circ} \mathrm{C}$ with acetyl bromide in acetic acid, 8:92 (v/v) and then treated with powdered $\mathrm{Zn}(50 \mathrm{mg}$ ) for $40 \mathrm{~min}$ at room temperature. The 
lignin degradation products were then acetylated for $1 \mathrm{~h}$ in $1.1 \mathrm{~mL}$ of dichloromethane containing $0.2 \mathrm{~mL}$ of acetic anhydride and $0.2 \mathrm{~mL}$ of pyridine. In order to assess the presence of naturally acetylated lignin units, the DFRC method was slightly modified to use propionylating reagents instead of acetylating ones (so-called DFRC'), as previously described (Ralph and Lu, 1998; del Río et al., 2007b). The lignin degradation products released by DFRC and DFRC' were analyzed in a GCMS-QP2010plus instrument (Shimadzu Co., Kyoto, Japan) using a capillary column (DB5MS $30 \mathrm{~m} \times 0.25 \mathrm{~mm}$ I.D., $0.25 \mu \mathrm{m}$ film thickness). The oven temperature was heated from $140(1 \mathrm{~min})$ to $250^{\circ} \mathrm{C}$ at a rate of $3^{\circ} \mathrm{C} \mathrm{min}{ }^{-1}$, then ramped at $3^{\circ} \mathrm{C} \mathrm{min}^{-1}$ to $280^{\circ} \mathrm{C}(1 \mathrm{~min})$

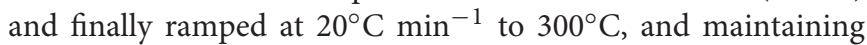
the final temperature for $18 \mathrm{~min}$. The injector temperature was set at $250^{\circ} \mathrm{C}$ while the transfer line was kept at $310^{\circ} \mathrm{C}$. The

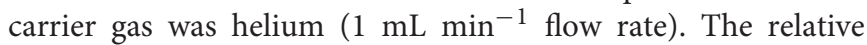
molar abundances of the released lignin degradation products were determined using the molecular weights of their respective acetylated or propionylated compounds.

\section{RESULTS}

\section{Main Constituents of Rice Husks and Straw}

The relative abundances of the main constituents (water-soluble material, acetone extractives, methanol extractives, Klason lignin, acid-soluble lignin, hemicelluloses, cellulose, proteins, and ash) of the rice husks and straw selected for this study are shown in Table 1. The lignin content in rice husks amounted up to $22.5 \%$ (including Klason and acid-soluble lignin contents) and was significantly higher than the lignin content in rice straw, where it accounted for $13.5 \%$. On the other hand, the rice straw presented a higher content of extractives (totaling 17.3\%, including acetone, methanol, and water-soluble extractives) than rice husks (10.7\%). Both residues presented similar contents of hemicelluloses (28.3\% in rice husks and $27.8 \%$ in rice straw), and cellulose (27.2\% in rice husks and $24.0 \%$ in rice straw), and a very low content of proteins $(0.7-0.9 \%)$. Also, both residues presented a high content of ash $(10.6 \%$ in rice husks and $16.5 \%$ in rice

TABLE 1 | Abundance (in percentage) of the main constituents of the dry weight of rice (Oryza sativa L.) husks and straw. ${ }^{a}$

\begin{tabular}{lrr}
\hline & Rice husk & Rice straw \\
\hline Acetone extractives & $4.3 \pm 0.3$ & $3.4 \pm 0.1$ \\
Methanol extractives & $1.9 \pm 0.3$ & $5.8 \pm 0.3$ \\
Water-soluble material & $4.5 \pm 0.3$ & $8.1 \pm 0.2$ \\
Klason ligninb & $20.0 \pm 0.1$ & $12.4 \pm 0.2$ \\
Acid-soluble lignin & $2.5 \pm 0.0$ & $1.1 \pm 0.0$ \\
Hemicelluloses & $28.3 \pm 0.7$ & $27.8 \pm 0.2$ \\
a-Cellulose & $27.2 \pm 0.2$ & $24.0 \pm 0.6$ \\
Proteins & $0.7 \pm 0.1$ & $0.9 \pm 0.1$ \\
Ash & $10.6 \pm 0.2$ & $16.5 \pm 0.3$
\end{tabular}

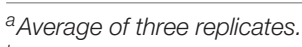

${ }^{b}$ Corrected for proteins and ash. straw), which mostly corresponded to silica, as indicated by other authors (Chandrasekhar et al., 2003; Salanti et al., 2010).

\section{Lignin Composition as Obtained by Py-GC/MS}

The whole cell walls of rice husks and straw, and their isolated MWLs, were first analyzed by Py-GC/MS that provided useful information regarding the composition of the lignocellulosic materials. The pyrograms of the whole cell walls of rice husks (Figure 1A) and rice straw (Figure 1B) showed compounds released from both carbohydrates (peaks a-q) and lignin (peaks 1-33). The identities and relative molar abundances of the released lignin-derived phenolic compounds are listed in Table 2, whereas the identities of the carbohydrate-derived compounds are detailed in the legend of Figure 1. Interestingly, the pyrolysis of rice husks released higher amounts of lignin-derived compounds, whereas the pyrolysis of rice straw released higher amounts of carbohydrate-derived compounds, in agreement with the higher lignin content observed in rice husks $(22.5 \%)$ compared to rice straw (13.5\%), as shown in Table 1. In both cases, the main phenolic compounds released were 4vinylguaiacol (8) and 4-vinylphenol (9). The pyrograms of the MWLs isolated from rice husks (Figure 1C) and rice straw (Figure 1D) only released phenolic compounds arising from lignin (and from $p$-hydroxycinnamates), that, in general terms, matched the profile of the phenolic compounds released from the corresponding whole cell walls (Figures 1A,B). The most abundant phenolic compounds released from both lignins were 4-vinylguaiacol (8) and 4-vinylphenol (9), as occurred in the pyrolysis of their respective whole cell walls. In addition, important amounts of phenolic compounds derived from guaiacyl (G)-lignin units, such as guaiacol (2), 4methylguaiacol (5), and 4-ethylguaiacol (7), among others, were released from both lignins. Phenolic compounds derived from p-hydroxycinnamyl (H)-lignin units, such as phenol (1), 4methylphenol (4), 4-ethylphenol (6), and from syringyl (S)lignin units, such as syringol (12), 4-methylsyringol (17), 4ethylsyringol (19), and 4-vinylsyringol (22), among others, were also released from both lignins, although in much lower amounts than their respective G-counterparts. In principle, the H:G:S composition of both lignins could be assessed from the relative abundances of the phenolic compounds derived from the different $\mathrm{H}, \mathrm{G}$, and S-lignin units. However, in the case of grasses, $p$-hydroxycinnamates ( $p$-coumarates and ferulates) are also important part of the lignins, with $p$-coumarates acylating the lignin side-chains, and ferulates acylating the arabinosyl residues of arabinoxylans and also forming covalent linkages with the lignin core (Ralph, 2010; Hatfield et al., 2017). p-Hydroxycinnamates are known to decarboxylate upon pyrolysis producing the respective 4vinylphenol (from $p$-coumarates) and 4-vinylguaiacol (from ferulates), which hinder the effective estimation of the lignin H:G:S composition (del Río et al., 1996, 2007a). A close estimation of the lignin $\mathrm{H}: \mathrm{G}: \mathrm{S}$ compositions were, however, obtained by ignoring the 4-vinylpyhenol (that can arise from both $\mathrm{H}$-lignin and $p$-coumarates) and 4 -vinylguaiacol (that can 
arise from G-lignin and from ferulates), as well as the respective 4-vinylsyringol, as previously and successfully done for other grasses (del Río et al., 2012a,b, 2015, 2018; Rencoret et al., 2015). The lignin composition thus estimated is shown in Table 2, and indicated that the lignin from rice husks presented a H:G:S composition of 13:73:14 (S/G ratio of 0.19 ) where as the lignin from rice straw presented a H:G:S composition of 16:61:23 (S/G ratio of 0.37 ). Therefore, the Py-GC/MS data indicated that both lignins were highly enriched in G-lignin units with the occurrence of lower amounts of $\mathrm{H}$ - and S-lignin units, with the lignin of rice husks being particularly highly enriched in G-units.
The occurrence of $p$-hydroxycinnamates ( $p$-coumarates and ferulates) in these lignins was confirmed by performing the pyrolysis in the presence of a methylating reagent, TMAH. Pyrolysis in the presence of TMAH (Py-TMAH) prevents decarboxylation of $p$-hydroxycinnamates and releases them intact as their fully methylated derivatives (del Río et al., 1996, 2007a). The Py-TMAH pyrograms of the whole cell walls of rice husks and straw and of their respective isolated MWLs are shown in Figure 2, and clearly show the release of important amounts of the fully methylated derivatives of $p$-coumaric (methyl trans-4-O-methyl-p-coumarate, $p C A$ ) and

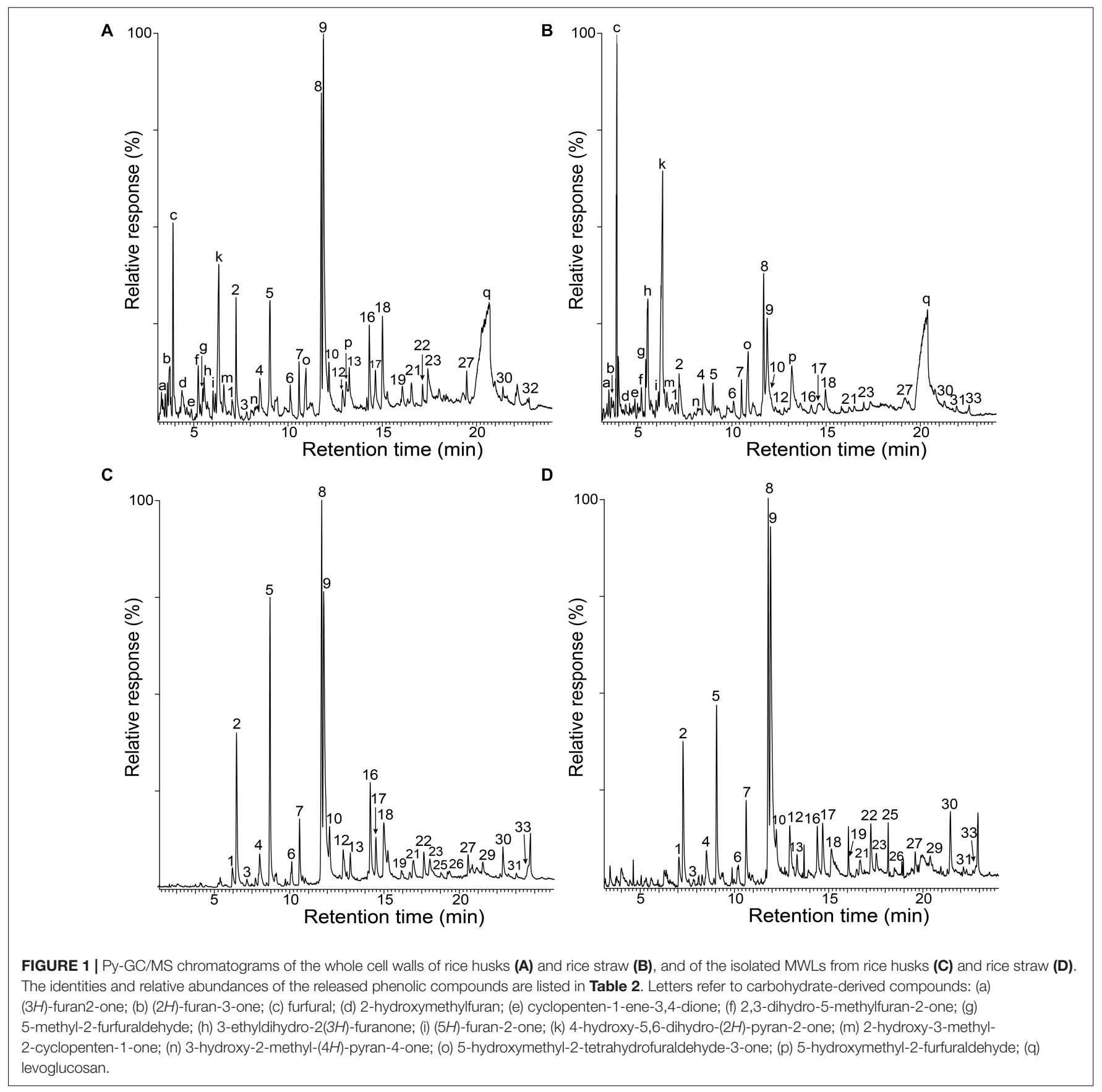


TABLE 2 | Identities and relative molar abundances of the compounds released after Py-GC/MS of whole cell walls (CW) of rice (Oryza sativa L.) husks and straw and their respective isolated MWLS.

\begin{tabular}{|c|c|c|c|c|c|c|}
\hline \multirow[b]{2}{*}{ Label } & \multirow[b]{2}{*}{ Compound } & \multirow[b]{2}{*}{ Origin } & \multicolumn{2}{|c|}{ Rice husks } & \multicolumn{2}{|c|}{ Rice straw } \\
\hline & & & $\mathrm{CW}$ & MWL & $\mathrm{CW}$ & MWL \\
\hline 1 & Phenol & $\mathrm{H}$ & 1.4 & 2.1 & 2.3 & 2.7 \\
\hline 2 & Guaiacol & G & 6.4 & 8.8 & 5.1 & 8.0 \\
\hline 3 & 3-methylphenol & $\mathrm{H}$ & 0.8 & 0.6 & 0.9 & 0.6 \\
\hline 4 & 4-methylphenol & $\mathrm{H}$ & 1.8 & 3.1 & 3.5 & 3.4 \\
\hline 5 & 4-methylguaiacol & $\mathrm{G}$ & 8.3 & 13.1 & 5.9 & 8.3 \\
\hline 6 & 4-ethylphenol & $\mathrm{H}$ & 1.4 & 0.5 & 2.0 & 0.7 \\
\hline 7 & 4-ethylguaiacol & $\mathrm{G}$ & 2.5 & 2.9 & 4.6 & 3.8 \\
\hline 8 & 4-vinylguaiacol & $\mathrm{G} / \mathrm{FA}$ & 12.4 & 15.4 & 19.6 & 14.5 \\
\hline 9 & 4-vinylphenol & $\mathrm{H} / p \mathrm{CA}$ & 33.4 & 27.1 & 31.2 & 30.6 \\
\hline 10 & Eugenol & G & 3.3 & 2.3 & 0.7 & 2.5 \\
\hline 11 & 4-allylphenol & $\mathrm{H}$ & 0.3 & 0.3 & 0.3 & 0.4 \\
\hline 12 & Syringol & S & 1.0 & 1.8 & 2.1 & 3.5 \\
\hline 13 & cis-isoeugenol & $\mathrm{G}$ & 2.2 & 1.1 & 0.6 & 1.0 \\
\hline 14 & cis-4-propenylphenol & $\mathrm{H}$ & 0.2 & 0.2 & 0.2 & 0.2 \\
\hline 15 & trans-4-propenylphenol & $\mathrm{H}$ & 0.6 & 0.6 & 1.1 & 0.5 \\
\hline 16 & trans-isoeugenol & G & 4.3 & 4.7 & 2.6 & 2.6 \\
\hline 17 & 4-methylsyringol & S & 2.4 & 1.9 & 1.7 & 2.6 \\
\hline 18 & Vanillin & G & 5.8 & 4.6 & 5.8 & 3.6 \\
\hline 19 & 4-ethylsyringol & $S$ & 1.0 & 0.6 & 0.5 & 0.7 \\
\hline 20 & Vanillic acid methyl ester & G & 0.3 & 0.4 & 0.2 & 0.4 \\
\hline 21 & Acetoguaiacone & $\mathrm{G}$ & 0.9 & 0.9 & 0.8 & 0.7 \\
\hline 22 & 4-vinylsyringol & $S$ & 0.9 & 1.2 & 0.3 & 2.2 \\
\hline 23 & Guaiacylacetone & G & 2.8 & 1.3 & 2.2 & 1.1 \\
\hline 24 & 4-allylsyringol & $S$ & 0.2 & 0.2 & 0.4 & 0.3 \\
\hline 25 & Propiovanillone & G & 0.8 & 0.4 & 0.2 & 0.1 \\
\hline 26 & cis-4-propenylsyringol & S & 0.2 & 0.2 & 0.5 & 0.3 \\
\hline 27 & trans-4-propenylsyringol & $S$ & 1.1 & 0.8 & 1.6 & 0.9 \\
\hline 28 & Vanillic acid & G & 0.4 & 0.6 & 0.0 & 0.2 \\
\hline 29 & Syringaldehyde & S & 0.6 & 0.7 & 0.6 & 0.8 \\
\hline 30 & Acetosyringone & S & 0.5 & 1.3 & 1.4 & 2.5 \\
\hline 31 & Syringylacetone & S & 0.3 & 0.3 & 1.0 & 0.3 \\
\hline 32 & trans-coniferaldehyde & $\mathrm{G}$ & 1.5 & 0.0 & 0.0 & 0.0 \\
\hline \multirow[t]{5}{*}{33} & Propiosyringone & S & 0.1 & 0.1 & 0.3 & 0.2 \\
\hline & $\% \mathrm{H}^{*}=$ & & 12.2 & 13.0 & 21.0 & 16.2 \\
\hline & $\% G^{*}=$ & & 74.2 & 73.0 & 58.4 & 61.0 \\
\hline & $\% \mathrm{~S}^{*}=$ & & 13.6 & 14.0 & 20.6 & 22.8 \\
\hline & $\mathrm{S} / \mathrm{G}$ ratio ${ }^{*}=$ & & 0.18 & 0.19 & 0.35 & 0.37 \\
\hline
\end{tabular}

${ }^{*}$ Calculated without taken into account the vinyl compounds 8, 9, and 22. $H$, p-hydroxyphenyl lignin units; $G$, guaiacyl lignin units; S, syringyl lignin units; $p C A$, p-coumarates; FA, ferulates.

ferulic (methyl 4-O-methyl-ferulate, FA) acids. Therefore, the Py-TMAH analysis conclusively demonstrated the presence of significant amounts of $p$-coumarates and ferulates in the lignins of rice husks and rice straw.

\section{Lignin Units and Inter-Unit Linkages as Seen by 2D-NMR}

Additional information about the composition of the lignin units as well as the inter-unit linkages present in the lignins from rice husks and straw were obtained by 2D-NMR spectroscopy (in HSQC experiments). The side-chain $\left(\delta_{C} / \delta_{H} 48-90 / 2.5-5.7\right)$ and the aromatic/unsaturated $\left(\delta_{C} / \delta_{H} 90-150 / 6.0-7.8\right)$ regions of the HSQC spectra of the whole cell walls of rice husks and straw and of their isolated MWLs, are shown in Figures 3, 4. The spectra of the whole cell walls showed signals from carbohydrates and lignin, whereas the spectra of the isolated MWLs showed mostly signals from the lignin polymer, evidencing the efficiency of the lignin isolation process. The HSQC spectrum of the whole cell walls of rice husks presented higher intensities of the lignin signals than the spectrum of the whole cell walls of rice straw, as corresponded to their higher lignin content. The lignin correlation signals assigned in the HSQC spectra are listed in Table 3 and the main lignin units and substructures identified are depicted in Figure 5. Carbohydrate signals from the different correlations of xylans $\left(\mathrm{X}_{2}, \mathrm{X}_{3}, \mathrm{X}_{4}\right.$, and $\left.\mathrm{X}_{5}\right)$, including acetylated xylans $\left(\mathrm{X}_{2}^{\prime}\right.$ and $\mathrm{X}_{3}^{\prime}$ ), were predominant in the aliphatic sidechain region of the spectra of the whole cell walls, partially overlapping with some lignin signals. The spectra of the isolated MWLs, however, exhibited predominantly lignin signals that matched those present in the HSQC spectra of their respective whole cell walls indicating that the MWL preparations were representative of the native lignins.

In the aliphatic-oxygenated region of the spectra, besides the signal from methoxyls, the rest of signals corresponded to the different lignin inter-unit linkages. Typical signals from the $\mathrm{C}_{\alpha} / \mathrm{H}_{\alpha}, \mathrm{C}_{\beta} / \mathrm{H}_{\beta}$, and $\mathrm{C}_{\gamma} / \mathrm{H}_{\gamma}$ correlations of $\beta-O-4^{\prime}$ alkyl-aryl ethers (A), phenylcoumarans (B), resinols (C), dibenzodioxocins (D), spirodienones (F), and cinnamyl alcohol end-groups (I), were observed in this region of the spectra. The occurrence of strong signals from condensed lignin structures, such as phenylcoumarans (B), and particularly from dibenzodioxocins (D), which essentially involved G-lignin units linked by $\beta-5$ and $5-5$ bonds, respectively, was indicative of the enrichment of G-lignin units in these lignins. An important feature observed in the HSQC spectra of these lignins was the occurrence of strong signals from $\gamma$-acylated lignin structures, mainly from $\gamma$-acylated $\beta-O-4^{\prime}$ alkyl aryl ethers $\left(\mathbf{A}^{\prime}\right)$. The occurrence of intense signals at around $\delta_{C} / \delta_{H}$ 62.7/3.83-4.30, assigned to the $\mathrm{C}_{\gamma} / \mathrm{H}_{\gamma}$ correlations of $\gamma$-acylated $\beta-O-4^{\prime}$ substructures $\left(\mathrm{A}_{\gamma}^{\prime}\right)$, revealed that a significant part of the lignins from rice husks and straw were acylated at the $\gamma-\mathrm{OH}$ of the lignin side-chain. Signals for the $\mathrm{C}_{\beta} / \mathrm{H}_{\beta}$ correlations of $\gamma$-acylated $\beta-O-4^{\prime}$ substructures linked to S-units $\left(\mathrm{A}_{\beta(S)}^{\prime}\right)$ overlapped with those of normal $\gamma-\mathrm{OH} \beta-O-4^{\prime}$ substructures linked to G-units $\left(\mathrm{A}_{\beta(G)}\right)$ at around $\delta_{C} / \delta_{H} 83.0 / 4.33$, whereas the signal for the $\mathrm{C}_{\beta} / \mathrm{H}_{\beta}$ correlations of $\gamma$-acylated $\beta-O-4^{\prime}$ substructures linked to G-units $\left(\mathrm{A}_{\beta(G)}^{\prime}\right)$ were clearly observed at around $\delta_{C} / \delta_{H} 80.5 / 4.53$. The extent of $\gamma$-acylation of these lignins were estimated from the $\mathrm{C}_{\gamma} / \mathrm{H}_{\gamma}$ correlation signals of normal $\gamma$-OH $\left(\mathrm{A}_{\gamma}\right)$ and $\gamma$-acylated $\beta-O-4^{\prime}$ substructures $\left(\mathrm{A}_{\gamma}^{\prime}\right)$ in the HSQC spectra of the isolated MWLs, where the signals from carbohydrates do not interfere, and revealed that $10 \%$ of the lignin side-chains of rice husks, and $12 \%$ of the lignin side-chains of rice straw were acylated at the $\gamma-\mathrm{OH}$. Likewise, signals for the $\mathrm{C}_{\alpha} / \mathrm{H}_{\alpha}$ and $\mathrm{C}_{\beta} / \mathrm{H}_{\beta}$ correlations of $\gamma$-acylated tetrahydrofuran structures arising from $\beta-\beta$-coupling 

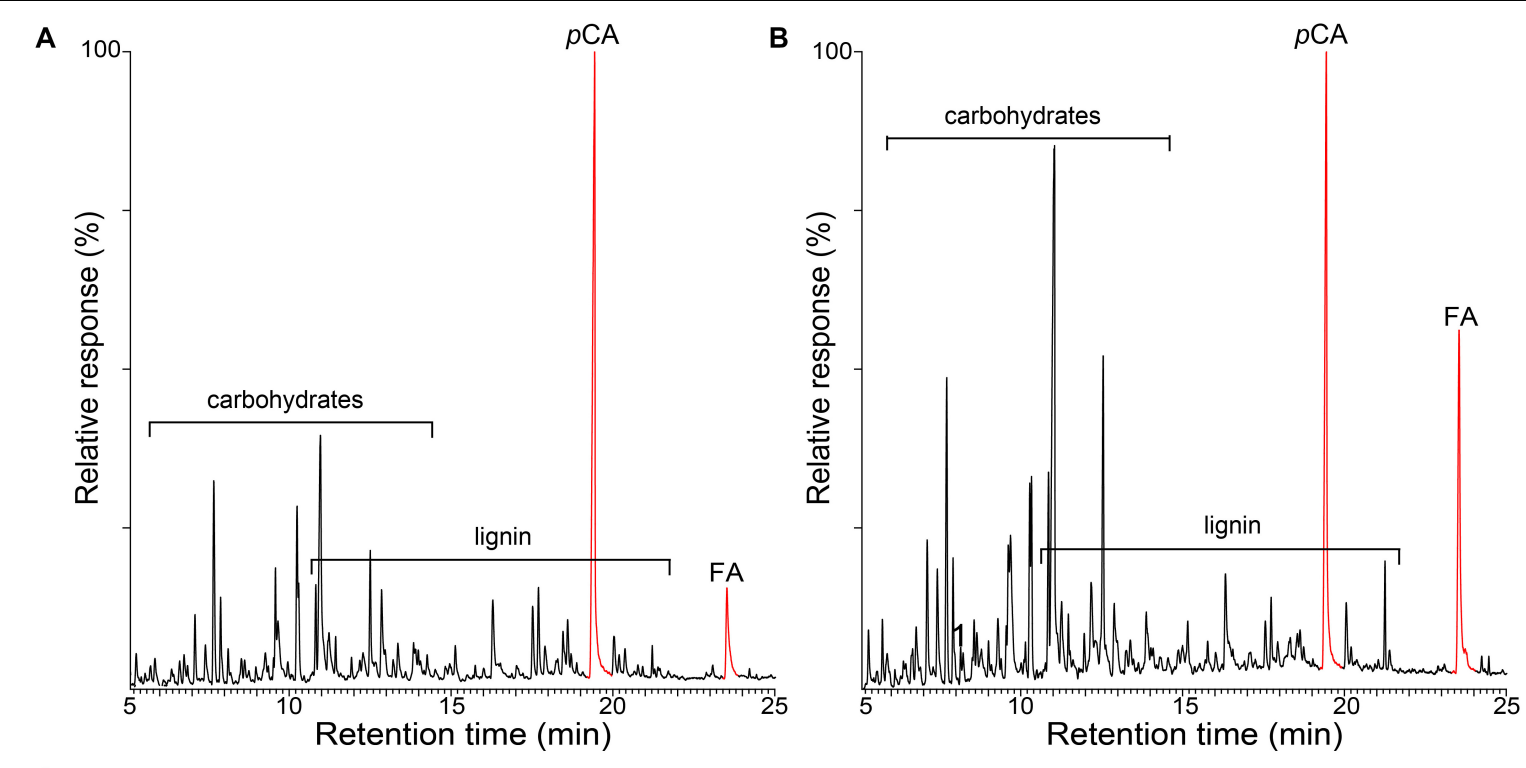

C

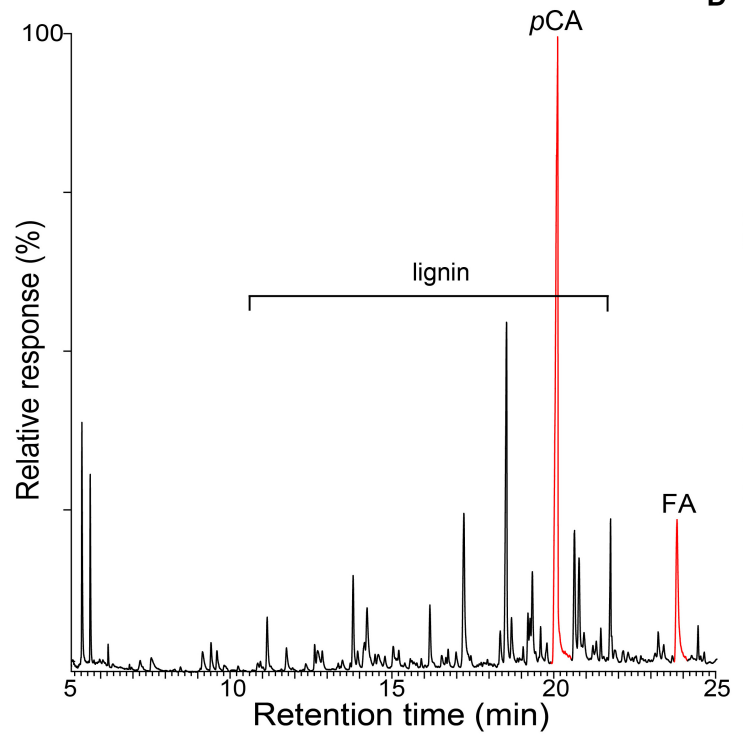

。

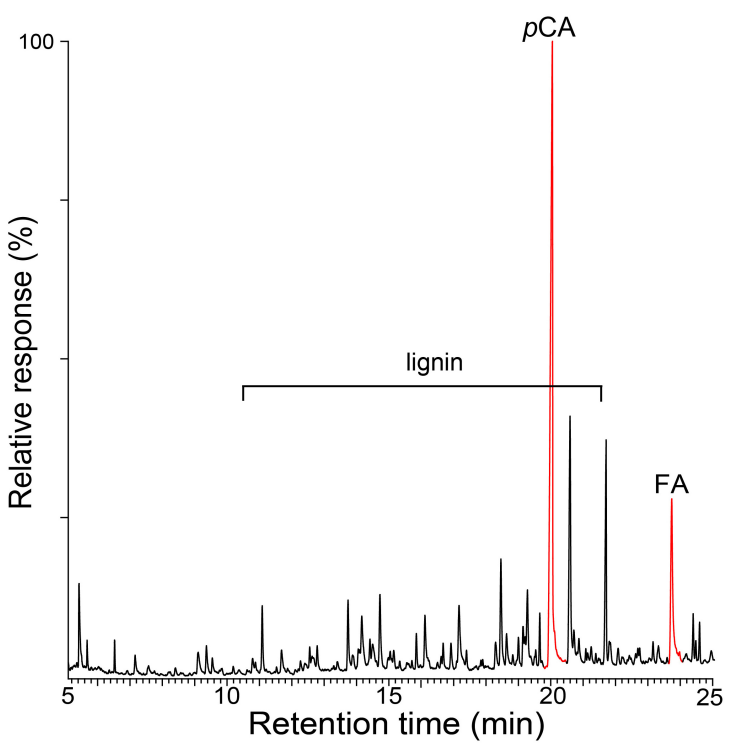

FIGURE 2 | Py-TMAH-GC/MS chromatograms of the whole cell walls of rice husks (A) and rice straw (B), and of the isolated MWLs from rice husks (C) and rice straw (D). pCA is the fully methylated $p$-coumaric acid (methyl trans-4-O-methyl-p-coumarate); FA is the fully methylated ferulic acid (methyl

trans-4-O-methyl-ferulate).

of two $\gamma$-acylated monolignols $\left(\mathbf{C}^{\prime}\right)$ could be observed in the spectrum of the lignin from rice straw at $\delta_{C} / \delta_{H} 82.6 / 5.00\left(C_{\alpha}^{\prime}\right)$ and $49.7 / 2.58\left(\mathrm{C}_{\beta}^{\prime}\right)$, although at lower intensities, providing additional evidences of the partial acylation of the lignin sidechain. In addition, a signal for the $\mathrm{C}_{\gamma} / \mathrm{H}_{\gamma}$ correlations of cinnamyl alcohol end-groups acylated at the $\gamma-\mathrm{OH}$ of the lignin side-chain $\left(\mathbf{I}^{\prime}\right)$ was also observed at $\delta_{C} / \delta_{H}$ 64.0/4.77 $\left(\mathrm{I}^{\prime} \gamma(p C A)\right)$. This signal is clearly distinctive of $\gamma$-acylation with $p$-coumarates, and is different from the signals of $\gamma$-acylation with other groups, such as acetates that should appear at $\delta_{C} / \delta_{H}$ $64.0 / 4.65$, or $p$-hydroxybenzoates that should appear at $\delta_{C} / \delta_{H}$ 64.4/4.87 (Rencoret et al., 2018). Therefore, this signal clearly evidenced that the cinnamyl alcohol end-groups were partially acylated with $p$-coumarates, which may also be the main group acylating these lignins.

In the aromatic/unsaturated region of the HSQC spectra, the main correlation signals corresponded to the aromatic rings of the different lignin units $(\mathbf{H}, \mathbf{G}$, and $\mathbf{S})$, including $\mathrm{C} \alpha$-oxidized S-lignin units $\left(\mathbf{S}^{\prime}\right)$, as well as to the aromatic rings and the unsaturated side-chains of $p$-coumarates $(p \mathbf{C A})$ and ferulates (FA). The signals for $\mathrm{H}$-lignin units were only observed at low intensities, and in some cases overlapped with signals from proteins. Other signals in the aromatic/unsaturated region of the spectra were from the $\mathrm{C}_{\alpha} / \mathrm{H}_{\alpha}$ and $\mathrm{C}_{\beta} / \mathrm{H}_{\beta}$ correlations of cinnamyl alcohol endgroups (I) and for the $\mathrm{C}_{8} / \mathrm{H}_{8}$ correlations of cinnamaldehydes 

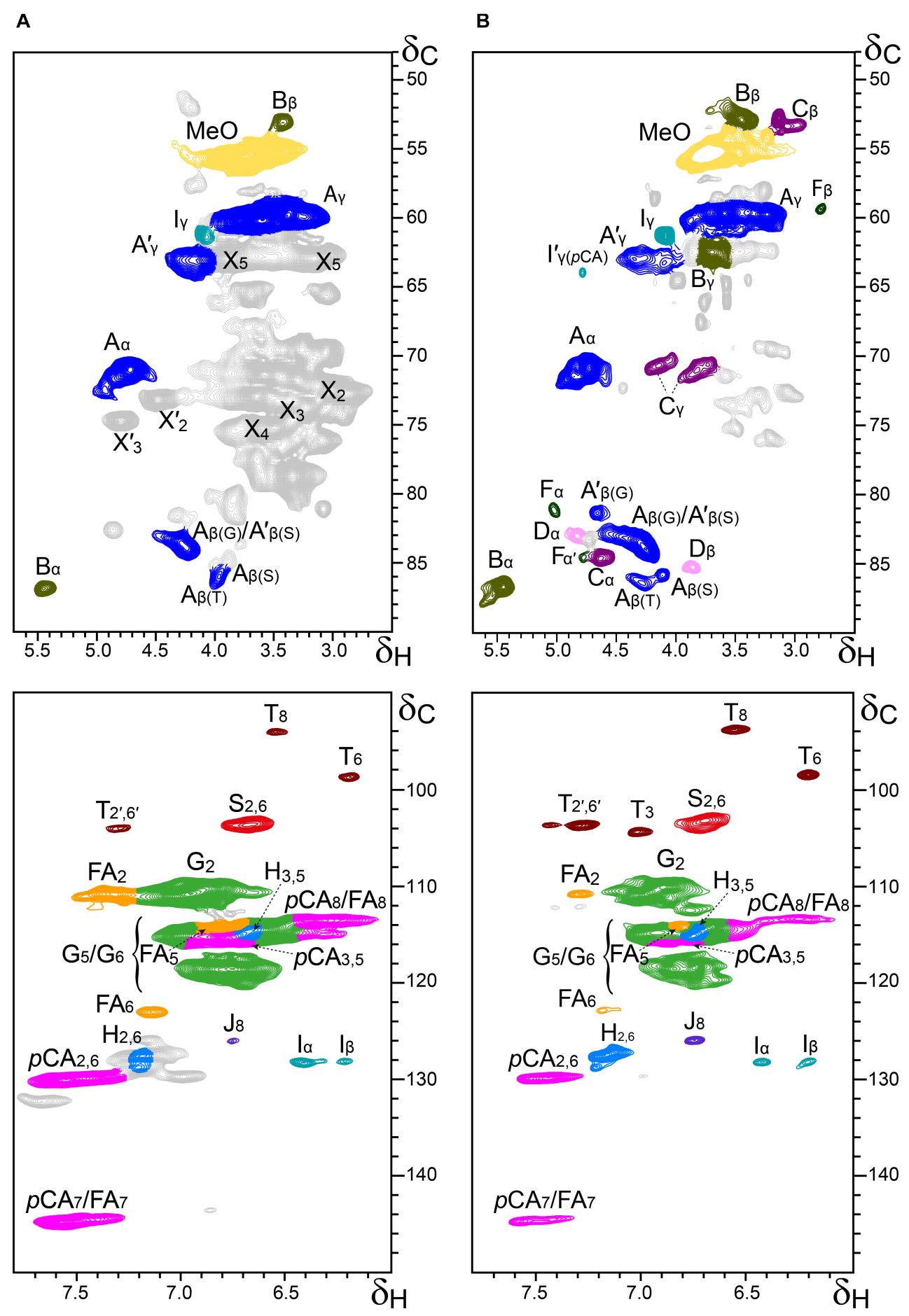

FIGURE 3 | Aliphatic-oxygenated $\left(\delta_{C} / \delta_{H} 48-90 / 2.5-5.7\right.$; top) and aromatic $\left(\delta_{C} / \delta_{H}\right.$ 90-150/6.0-7.8; bottom) regions from the 2D-HSQC-NMR spectra (in DMSO- $d_{6}$ ) of the whole cell walls from rice husks (A) and its isolated MWL (B). The main structures identified are drawn in Figure $\mathbf{5}$. See Table $\mathbf{3}$ for signal assignments.

(J). In addition, in this region of the spectra also appeared the two distinctive signals corresponding to the $\mathrm{C}_{8} / \mathrm{H}_{8}$ and $\mathrm{C}_{6} / \mathrm{H}_{6}$ correlations of tricin $(T)$, together with the signals for their $\mathrm{C}_{3} / \mathrm{H}_{3}$ and $\mathrm{C}_{2^{\prime}, 6^{\prime}} / \mathrm{H}_{2^{\prime}, 6^{\prime}}$ correlations (del Río et al., 2012b).
The structural characteristics of the lignins from rice husks and straw, such as the relative abundances of the different interunit linkages, $\beta-O-4^{\prime}$ aryl ethers $\left(\mathbf{A} / \mathbf{A}^{\prime}\right), \beta-5^{\prime}$ phenylcoumarans (B), $\beta-\beta^{\prime}$ resinols $(\mathbf{C}), \beta-\beta^{\prime}$ tetrahydrofurans $\left(\mathbf{C}^{\prime}\right), 5-5^{\prime}$ dibenzodioxocins $(\mathbf{D}), \beta-1^{\prime}$ spirodienones $(\mathbf{F})$, and 

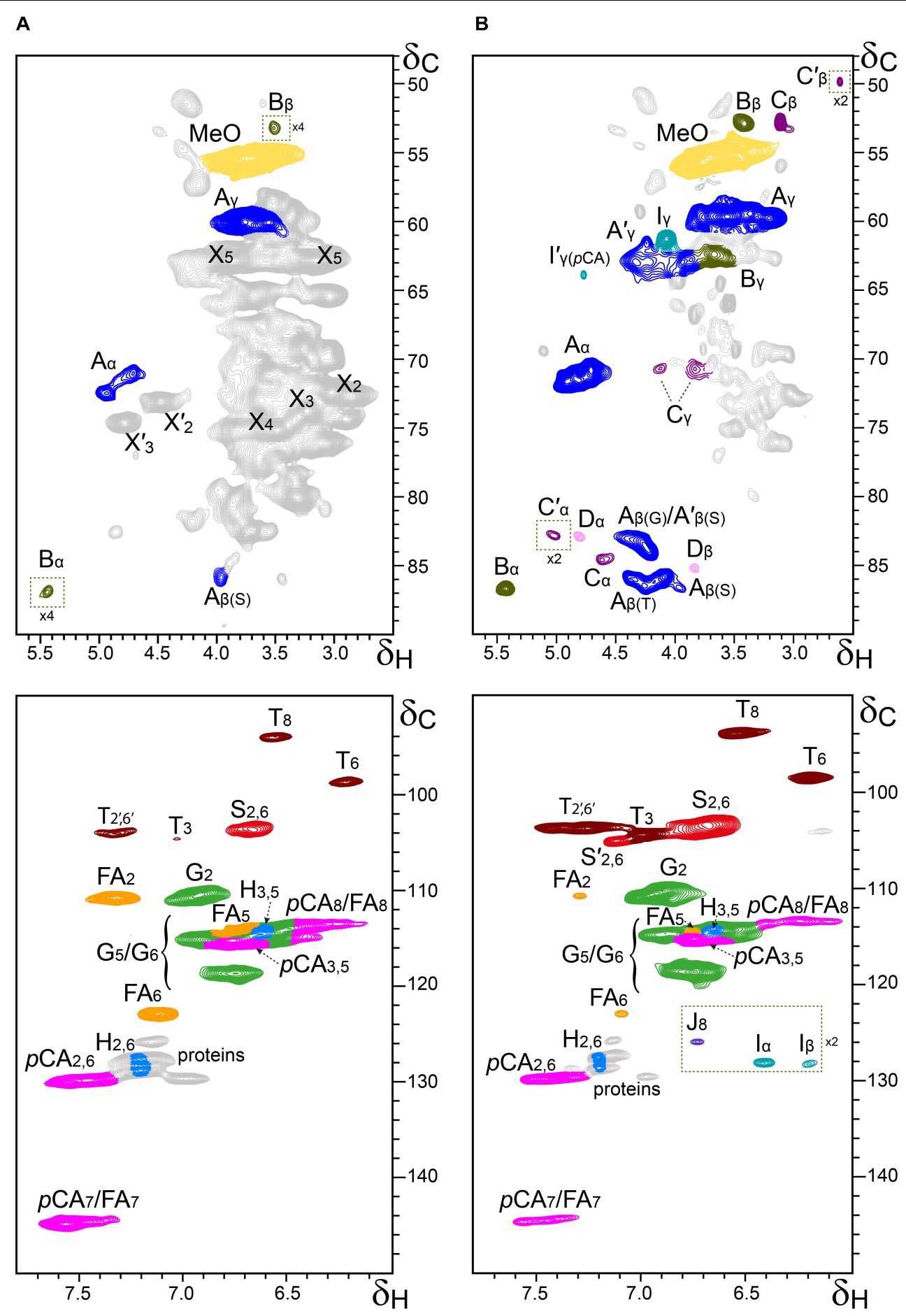

FIGURE 4 | Aliphatic-oxygenated $\left(\delta_{C} / \delta_{H} 48-90 / 2.5-5.7\right.$; top) and aromatic $\left(\delta_{C} / \delta_{H} 90-150 / 6.0-7.8\right.$; bottom) regions from the 2D-HSQC-NMR spectra (in DMSO- $d_{6}$ ) of the whole cell walls from rice straw (A) and its isolated MWL (B). The main structures identified are drawn in Figure $\mathbf{5}$. See Table $\mathbf{3}$ for signal assignments.

cinnamyl alcohol (I), and cinnamaldehyde ( $\mathrm{J}$ ) end-groups, the percentage of $\gamma$-acylation of the lignin side-chain, the relative abundances of the lignin units $(\mathbf{H}, \mathbf{G}$, and $\mathbf{S}), p$-coumarates $(p$ CA), ferulates (FA), and tricin $(\mathbf{T})$, estimated from volume integration of the signals in the HSQC spectra, are indicated in
Table 4. The 2D-NMR data confirmed that the lignins from rice husks and straw were enriched in G-lignin units and depleted in $\mathrm{H}$ - and S-lignin units, as already revealed by Py-GC/MS. The H:G:S composition of the lignins from rice husks (7:81:12; S/G of 0.15$)$ and rice straw (5:71:24; S/G of 0.34 ) basically matched 
TABLE 3 | Assignments of the lignin ${ }^{1} \mathrm{H} /{ }^{13} \mathrm{C}$ correlation signals in the 2D HSQC spectra from the whole cell walls of rice husks and straw and their isolated MWLS (in $\mathrm{DMSO}-d_{6}$ ).

\begin{tabular}{|c|c|c|}
\hline Label & $\begin{array}{l}\delta_{C} / \delta_{H} \\
(p p m)\end{array}$ & Assignment \\
\hline $\mathrm{C}_{\beta}^{\prime}$ & $49.7 / 2.58$ & $\mathrm{C}_{\beta} / \mathrm{H}_{\beta}$ in $\gamma$-acylated $\beta-\beta^{\prime}$ tetrahydrofurans $\left(\mathbf{C}^{\prime}\right)$ \\
\hline $\mathrm{B}_{\beta}$ & $53.1 / 3.41$ & $\mathrm{C}_{\beta} / \mathrm{H}_{\beta}$ in $\beta-5^{\prime}$ phenylcoumarans $(\mathbf{B})$ \\
\hline $\mathrm{C}_{\beta}$ & $53.6 / 3.07$ & $\mathrm{C}_{\beta} / \mathrm{H}_{\beta}$ in $\beta-\beta^{\prime}$ resinols $(\mathbf{C})$ \\
\hline$-\mathrm{OCH}_{3}$ & $55.6 / 3.73$ & $\mathrm{C} / \mathrm{H}$ in methoxyls \\
\hline$A_{\gamma}$ & $\begin{array}{l}59.4 / 3.20 \\
3.56\end{array}$ & $\begin{array}{l}\mathrm{C}_{\gamma} / \mathrm{H}_{\gamma} \text { in normal }\left(\gamma \text {-hydroxylated) } \beta-\mathrm{O}-4^{\prime}\right. \\
\text { substructures }(\mathbf{A})\end{array}$ \\
\hline $\mathrm{F}_{\beta}$ & $59.3 / 2.76$ & $\mathrm{C}_{\beta} / \mathrm{H}_{\beta}$ in spirodienones $(\mathbf{F})$ \\
\hline $\mathrm{I}_{\gamma}$ & $61.5 / 4.09$ & $\mathrm{C}_{\gamma} / \mathrm{H}_{\gamma}$ in cinnamyl alcohol end-groups (I) \\
\hline $\mathrm{B}_{\gamma}$ & $62.6 / 3.68$ & $\mathrm{C}_{\gamma} / \mathrm{H}_{\gamma}$ in $\beta-5^{\prime}$ phenylcoumarans $(\mathbf{B})$ \\
\hline $\mathrm{A}_{\gamma}^{\prime}$ & $\begin{array}{l}62.7 / 3.83 \\
4.30\end{array}$ & $\mathrm{C}_{\gamma} / \mathrm{H}_{\gamma}$ in $\gamma$-acylated $\beta-\mathrm{O}-4^{\prime}$ substructures $\left(\mathbf{A}^{\prime}\right)$ \\
\hline$I^{\prime} \gamma(p C A)$ & $64.0 / 4.77$ & $\begin{array}{l}\mathrm{C}_{\gamma} / \mathrm{H}_{\gamma} \text { in } \gamma \text {-p-coumaroylated cinnamyl alcohol } \\
\text { end-groups }\left(\mathbf{I}^{\prime}\right)\end{array}$ \\
\hline $\mathrm{C}_{\gamma}$ & $\begin{array}{l}71.0 / 3.82 \\
4.18\end{array}$ & $\mathrm{C}_{\gamma} / \mathrm{H}_{\gamma}$ in $\beta-\beta^{\prime}$ resinols $(\mathbf{C})$ \\
\hline$A_{\alpha}$ & $71.8 / 4.87$ & $\mathrm{C}_{\alpha} / \mathrm{H}_{\alpha}$ in $\beta-\mathrm{O}-4^{\prime}$ substructures $(\mathbf{A})$ \\
\hline $\mathrm{A}^{\prime} \beta(G)$ & $81.2 / 4.64$ & $\begin{array}{l}\mathrm{C}_{\beta} / \mathrm{H}_{\beta} \text { in } \gamma \text {-acylated } \beta-O-4^{\prime} \text { alkyl-aryl ethers }\left(\mathbf{A}^{\prime}\right) \\
\text { linked to a } \mathrm{G} \text { unit }\end{array}$ \\
\hline $\mathrm{F}_{\alpha}$ & $81.2 / 5.02$ & $\mathrm{C}_{\alpha} / \mathrm{H}_{\alpha}$ in spirodienones $(\mathbf{F})$ \\
\hline $\mathrm{C}_{\alpha}^{\prime}$ & $82.6 / 5.00$ & $\mathrm{C}_{\alpha} / \mathrm{H}_{\alpha}$ in $\gamma$-acylated $\beta-\beta^{\prime}$ tetrahydrofurans $\left(\mathbf{C}^{\prime}\right)$ \\
\hline $\mathrm{A}_{\beta(S)}^{\prime}$ & $83.0 / 4.33$ & $\begin{array}{l}\mathrm{C}_{\beta} / \mathrm{H}_{\beta} \text { in } \gamma \text {-acylated } \beta-O-4^{\prime} \text { alkyl-aryl ethers }\left(\mathbf{A}^{\prime}\right) \\
\text { linked to a } S \text { unit }\end{array}$ \\
\hline$D_{\alpha}$ & $83.3 / 4.82$ & $\mathrm{C}_{\alpha} / \mathrm{H}_{\alpha}$ in $5-5^{\prime}$ dibenzodioxocins (D) \\
\hline$A_{\beta(G)}$ & $83.9 / 4.28$ & $\begin{array}{l}\mathrm{C}_{\beta} / \mathrm{H}_{\beta} \text { in } \beta-\mathrm{O}-4^{\prime} \text { alkyl-aryl ethers }(\mathbf{A}) \text { linked to a } \\
\mathrm{G} \text { unit }\end{array}$ \\
\hline $\mathrm{C}_{\alpha}$ & $84.9 / 4.67$ & $\mathrm{C}_{\alpha} / \mathrm{H}_{\alpha}$ in $\beta-\beta^{\prime}$ resinols $(\mathbf{C})$ \\
\hline$F_{\alpha^{\prime}}$ & $85.2 / 4.72$ & $\mathrm{C}_{\alpha^{\prime}} / \mathrm{H}_{\alpha^{\prime}}$ in spirodienones $(\mathbf{F})$ \\
\hline$D_{\beta}$ & $85.4 / 3.86$ & $\mathrm{C}_{\beta} / \mathrm{H}_{\beta}$ in $5-5^{\prime}$ dibenzodioxocins (D) \\
\hline$A_{\beta(S)}$ & $85.9 / 4.12$ & $\begin{array}{l}\mathrm{C}_{\beta} / \mathrm{H}_{\beta} \text { in } \beta-\mathrm{O}-4^{\prime} \text { alkyl-aryl ethers }(\mathbf{A}) \text { linked to a } \\
\mathrm{S} \text { unit }\end{array}$ \\
\hline$A_{\beta(T)}$ & $86.1 / 4.31$ & $\begin{array}{l}\mathrm{C}_{\beta} / \mathrm{H}_{\beta} \text { in } \beta-\mathrm{O}-4^{\prime} \text { substructures }(\mathbf{A}) \text { linked to } \\
\text { tricin }\end{array}$ \\
\hline $\mathrm{B}_{\alpha}$ & $86.9 / 5.47$ & $\mathrm{C}_{\alpha} / \mathrm{H}_{\alpha}$ in phenylcoumarans $(\mathbf{B})$ \\
\hline $\mathrm{T}_{8}$ & $94.0 / 6.56$ & $\mathrm{C}_{8} / \mathrm{H}_{8}$ in tricin $(\mathbf{T})$ \\
\hline $\mathrm{T}_{6}$ & $98.7 / 6.22$ & $\mathrm{C}_{6} / \mathrm{H}_{6}$ in tricin $(\mathbf{T})$ \\
\hline $\mathrm{S}_{2,6}$ & $103.8 / 6.69$ & $\mathrm{C}_{2} / \mathrm{H}_{2}$ and $\mathrm{C}_{6} / \mathrm{H}_{6}$ in etherified syringyl units $(\mathbf{S})$ \\
\hline $\mathrm{T}_{2^{\prime}, 6^{\prime}}$ & $103.9 / 7.28$ & $\mathrm{C}_{2^{\prime}} / \mathrm{H}_{2^{\prime}}$ and $\mathrm{C}_{6^{\prime}} / \mathrm{H}_{6^{\prime}}$ in tricin $(\mathbf{T})$ \\
\hline $\mathrm{T}_{3}$ & 104.6/7.02 & $\mathrm{C}_{3} / \mathrm{H}_{3}$ in tricin $(\mathbf{T})$ \\
\hline $\mathrm{G}_{2}$ & $110.9 / 7.00$ & $\mathrm{C}_{2} / \mathrm{H}_{2}$ in guaiacyl units $(\mathbf{G})$ \\
\hline $\mathrm{FA}_{2}$ & $111.0 / 7.32$ & $\mathrm{C}_{2} / \mathrm{H}_{2}$ in ferulates (FA) \\
\hline$p \mathrm{CA}_{8} / \mathrm{FA}_{8}$ & $113.5 / 6.30$ & $\begin{array}{l}\mathrm{C}_{8} / \mathrm{H}_{8} \text { in } p \text {-coumarates (pCA) and ferulates } \\
\text { (FA) }\end{array}$ \\
\hline $\mathrm{H}_{3,5}$ & $114.5 / 6.68$ & $\mathrm{C}_{3} / \mathrm{H}_{3}$ and $\mathrm{C}_{5} / \mathrm{H}_{5}$ in $p$-hydroxyphenyl units $(\mathbf{H})$ \\
\hline $\mathrm{G}_{5} / \mathrm{G}_{6}$ & $\begin{array}{l}114.9 / 6.74 \\
6.94\end{array}$ & $\mathrm{C}_{5} / \mathrm{H}_{5}$ and $\mathrm{C}_{6} / \mathrm{H}_{6}$ in guaiacyl units $(\mathbf{G})$ \\
\hline $\mathrm{FA}_{5}$ & $115.4 / 6.88$ & $\mathrm{C}_{5} / \mathrm{H}_{5}$ in ferulates (FA) \\
\hline $\mathrm{pCA}_{3,5}$ & $115.5 / 6.77$ & $\mathrm{C}_{3} / \mathrm{H}_{3}$ and $\mathrm{C}_{5} / \mathrm{H}_{5}$ in $p$-coumarates (pCA) \\
\hline $\mathrm{FA}_{6}$ & $123.3 / 7.10$ & $\mathrm{C}_{6} / \mathrm{H}_{6}$ in ferulates (FA) \\
\hline$J_{8}$ & $126.3 / 6.76$ & $\mathrm{C}_{8} / \mathrm{H}_{8}$ in cinnamaldehyde end-groups $(\mathbf{J})$ \\
\hline $\mathrm{H}_{2,6}$ & $127.6 / 7.17$ & $\mathrm{C}_{2} / \mathrm{H}_{2}$ and $\mathrm{C}_{6} / \mathrm{H}_{6}$ in $p$-hydroxyphenyl units $(\mathbf{H})$ \\
\hline $\mathrm{I}_{\beta}$ & $128.2 / 6.21$ & $\mathrm{C}_{\beta} / \mathrm{H}_{\beta}$ in cinnamyl alcohol end-groups (I) \\
\hline $\mathrm{I}_{\alpha}$ & $128.4 / 6.44$ & $\mathrm{C}_{\alpha} / \mathrm{H}_{\alpha}$ in cinnamyl alcohol end-groups (I) \\
\hline$p \mathrm{CA}_{2,6}$ & $129.9 / 7.45$ & $\mathrm{C}_{2} / \mathrm{H}_{2}$ and $\mathrm{C}_{6} / \mathrm{H}_{6}$ in $p$-coumarates (pCA) \\
\hline$p \mathrm{CA}_{7} / \mathrm{FA}_{7}$ & $144.4 / 7.41$ & $\begin{array}{l}\mathrm{C}_{7} / \mathrm{H}_{7} \text { in } p \text {-coumarates (pCA) and } \\
\text { ferulates (FA) }\end{array}$ \\
\hline
\end{tabular}

those obtained upon Py-GC/MS, and indicated that the lignin from rice husks was particularly highly enriched in G-units. The 2D-NMR data also indicated that $p$-coumarates and ferulates were important components in the lignins from rice husks and straw, as already shown by Py-TMAH. Interestingly, ferulates were present in lower abundance in the isolated MWLs than in the respective whole cell walls, which was reflected in the $p C A / F A$ ratio, that was lower in the whole cell walls of (1.5 and 0.7 , in rice husks and straw) than in their respective isolated MWLs (3.0 and 4.0, in the MWLs of rice husks and straw). This indicated that ferulates were predominantly attached to the carbohydrates, which were removed during the MWL isolation process, whereas $p$-coumarates were mostly linked to the lignin structure. The occurrence of important amounts of $p$-coumarates in these lignins is an indication that they might be the groups acylating the $\gamma-\mathrm{OH}$ of the lignin side-chain, a typical feature of grass lignins (Ralph, 2010). Finally, the flavone tricin was also present in both lignins in significant amounts, being more abundant in the lignin from rice straw (27\% referred to total lignin units) than in the lignin from rice husks (7\%). However, it is important to note that the quantitation of tricin by $2 \mathrm{D}-\mathrm{NMR}$ (as well as of $p$-coumarates and ferulates) is overestimated due to the longer relaxation time of these end-units. The differences in the composition between the lignins from rice husks and straw, with the former being highly enriched in G-lignin units, were reflected in the relative abundances of the various interunit linkages, as shown in Table 4. Hence, the lignin from rice husks presented lower levels of $\beta-O-4$ alkyl aryl ether structures (65\% of all measured linkages) and higher levels of condensed structures such as phenylcoumarans (23\%), as corresponds to a lignin highly enriched in G-lignin units, together with minor amounts of other condensed structures (dibenzodioxocins, 5\%; resinols, $4 \%$; spirodienones, $3 \%$ ), as well as cinnamyl alcohol (6\%) and cinnamaldehyde (5\%) end-groups. On the other hand, the lignin from rice straw, with a slightly higher $\mathrm{S} / \mathrm{G}$ ratio, presented a higher level of $\beta-O-4$ alkyl aryl ether structures (78\%), and lower levels of phenylcoumarans (12\%), together with minor amounts of other condensed structures (dibenzodioxocins, 4\%; resinols, $4 \%$; tetrahydrofurans, $1 \%$; spirodienones, $1 \%$ ) and cinnamyl alcohol (6\%) and cinnamaldehyde (5\%) end-groups.

\section{Nature of Lignin Acylation as Seen by DFRC}

The HSQC spectra of the lignins of rice husks and straw revealed that they were partially acylated $(10-12 \%)$ at the $\gamma-\mathrm{OH}$ of the lignin side-chains but did not provide information regarding the nature of the acylating groups. To assess the nature of the acyl groups present at the $\gamma-\mathrm{OH}$ of the lignin side-chain, the MWLs were analyzed by DFRC, a chemical degradative method that cleaves $\beta$-ether bonds, the most abundant linkages in the lignin structure, releasing the lignin units that are involved in those bonds. A characteristic feature of this degradation method is that it maintains intact the ester bonds present at the $\gamma-\mathrm{OH}$ of the lignin side chain, and thus can provide important information about the nature of the groups acylating the $\gamma-\mathrm{OH}$. 

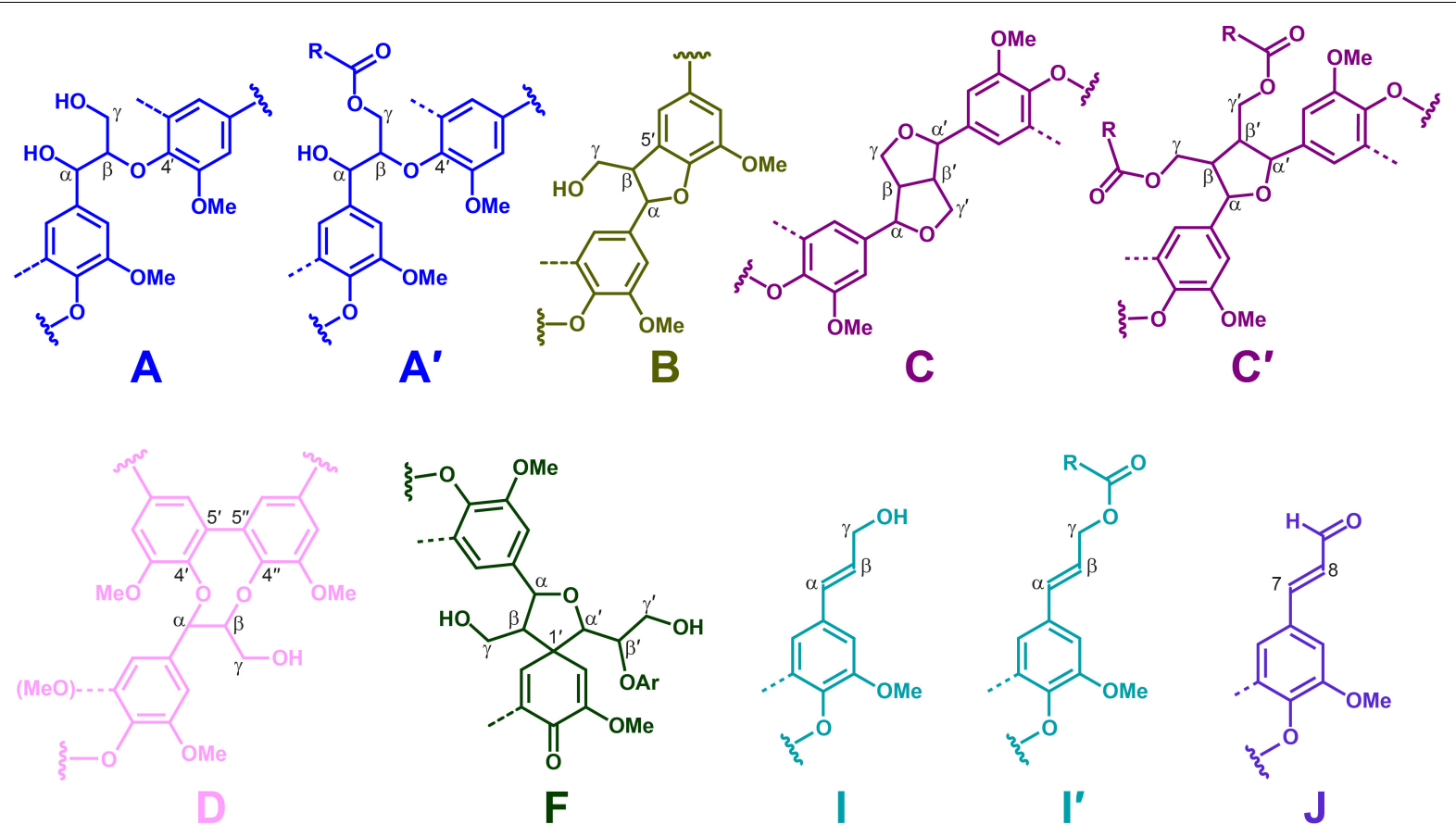

$\mathbf{F}$<smiles>CCOc1ccc(C(C)O)cc1</smiles><smiles>CCOc1ccc(C(C)O)cc1OC</smiles>

H

G<smiles>COc1cc(C(C)O)cc(OC)c1OC</smiles>

S<smiles>[R]C(=O)c1cc(OC)c(OC)c(OC)c1</smiles>

$\mathbf{S}^{\prime}$<smiles>CCOc1c(C)cc(C=CC=O)cc1OC</smiles>

$\mathbf{J}$

FIGURE 5 | Main structures identified in the NMR spectra of the lignins of rice husks and straw. A, $\beta-O-4^{\prime}$ alkyl-aryl ethers; $\mathbf{A}^{\prime}, \beta-O-4^{\prime}$ alkyl-aryl ethers acylated at the $\gamma-\mathrm{OH}$; B, phenylcoumarans; $\mathbf{C}$, resinols; $\mathbf{C}^{\prime}$, tetrahydrofurans acylated at the $\gamma-\mathrm{OH} ; \mathbf{D}$, dibenzodioxocins; $\mathbf{F}$, spirodienones; I, $p$-hydroxycinnamyl alcohol end-groups; $\mathbf{I}^{\prime}, p$-hydroxycinnamyl alcohol end-groups acylated at the $\gamma-\mathrm{OH} ; \mathbf{J}$, cinnamaldehyde end-groups; $\mathbf{p C A}, p$-coumarates; FA, ferulates; $\mathbf{H}$, $p$-hydroxyphenyl units; $\mathbf{G}$, guaiacyl units; $\mathbf{S}$, syringyl units; $\mathbf{S}^{\prime}$, C $\alpha$-oxidized S-units; $\mathbf{T}$, tricin. The structures are colored in order to match the signals in the HSQC spectra of Figures 3, 4.

The chromatograms of the DFRC degradation products released from the lignins of rice husks and straw (Figure 6) showed the occurrence of the cis- and trans-isomers of the $p$-hydroxyphenyl $(t \mathrm{H})$, guaiacyl $(c \mathrm{G}$ and $t \mathrm{G})$, and syringyl $(c S$ and $t S$ ) lignin monomers (as their acetate derivatives) arising from normal $\gamma$-OH lignin units involved in $\beta$-ether linkages. But more important, the chromatograms also showed the release of the cis- and trans-isomers of S-lignin units acylated with $p$-coumarates $\left(c S_{p C A}\right.$ and $\left.t S_{p C A}\right)$, as well as minor amounts of the guaiacyl analogs $\left(c \mathrm{G}_{p C A}\right.$ and $\left.t \mathrm{G}_{p C A}\right)$. The release of these compounds confirmed that $p$-coumarates were the groups partially acylating the $\gamma-\mathrm{OH}$ of these lignins, and that $p$-coumaroylation preferentially occurred over $S$ units. On the other hand, the lignins from many plants, including other grasses, also present acetate groups acylating the $\gamma-\mathrm{OH}$ of the lignin side-chain (Ralph, 1996; Ralph and Lu, 1998; del Río et al., 2007b,
2008). However, the original DFRC protocol cannot be used to assess the occurrence of naturally occurring acetates acylating the $\gamma-\mathrm{OH}$ of the lignin side chain because this degradation method uses acetate reagents that produces acetate derivatives; however, with a small modification of the original protocol by using propionylating reagents (socalled DFRC') it was possible to obtain information about the occurrence of acetate groups naturally acylating the $\gamma-\mathrm{OH}$ (Ralph and Lu, 1998; del Río et al., 2007b). The analysis of the lignins from rice husks and straw by DFRC' indicated that they were barely acylated with acetate groups (less than $0.5 \%)$, and confirmed that $p$-coumarate was the most important group acylating the $\gamma-\mathrm{OH}$. Interestingly, significant amounts of tricin $(\mathrm{T})$, as its acetate derivative, were also released from these lignins by DFRC (Figure 6), being more abundant in the lignin from rice straw than in the lignin from rice husks. 
TABLE 4 | Structural characteristics (lignin inter-unit linkage types, end-groups, $\gamma$-acylation, aromatic units, and $\mathrm{S} / \mathrm{G}$ ratio, cinnamate content, and tricin content) from integration of ${ }^{1} \mathrm{H} /{ }^{13} \mathrm{C}$ correlation signals in the HSQC spectra of the whole cell walls $(\mathrm{CW})$ of rice husks and rice straw and their isolated MWLs.

\begin{tabular}{|c|c|c|c|c|}
\hline & \multicolumn{2}{|c|}{ Rice husks } & \multicolumn{2}{|c|}{ Rice straw } \\
\hline & CW & MWL & CW & MWL \\
\hline \multicolumn{5}{|l|}{ Lignin inter-unit linkages (\%) } \\
\hline$\beta-O-4^{\prime}$ aryl ethers $\left(\mathbf{A} / \mathbf{A}^{\prime}\right)$ & - & 65 & - & 78 \\
\hline$\beta-5^{\prime}$ Phenylcoumarans (B) & - & 23 & - & 12 \\
\hline$\beta-\beta^{\prime}$ Resinols $(\mathbf{C})$ & - & 4 & - & 4 \\
\hline$\beta-\beta^{\prime}$ Tetrahydrofurans $\left(\mathbf{C}^{\prime}\right)$ & - & 0 & - & 1 \\
\hline 5-5' Dibenzodioxocins (D) & - & 5 & - & 4 \\
\hline$\beta-1^{\prime}$ Spirodienones $(\mathbf{F})$ & - & 3 & - & 1 \\
\hline \multicolumn{5}{|l|}{ Lignin end-groups ${ }^{a}$} \\
\hline Cinnamyl alcohol end-groups (I) & - & 6 & - & 6 \\
\hline Cinnamaldehyde end-groups (J) & - & 5 & - & 5 \\
\hline Lignin side-chain $\gamma$-acylation (\%) & - & 10 & - & 12 \\
\hline \multicolumn{5}{|l|}{ Lignin aromatic units ${ }^{b}$} \\
\hline $\mathbf{H}(\%)$ & 5 & 7 & 7 & 5 \\
\hline $\mathbf{G}(\%)$ & 85 & 81 & 71 & 71 \\
\hline $\mathbf{S}(\%)$ & 10 & 12 & 22 & 24 \\
\hline $\mathbf{S} / \mathbf{G}$ ratio & 0.12 & 0.15 & 0.31 & 0.34 \\
\hline \multicolumn{5}{|l|}{$p$-Hydroxycinnamates ${ }^{c}$} \\
\hline$p$-coumarates (pCA) & 28 & 12 & 39 & 16 \\
\hline ferulates (FA) & 19 & 4 & 53 & 4 \\
\hline pCA/FA ratio & 1.5 & 3.0 & 0.7 & 4.0 \\
\hline $\operatorname{Tricin}(\mathbf{T})^{c}$ & 5 & 7 & 18 & 27 \\
\hline
\end{tabular}

${ }^{a}$ Expressed as a fraction of the total lignin inter-unit linkage types $\boldsymbol{A}-\boldsymbol{F}$.

${ }^{b}$ Relative percentages $(H+G+S=100)$.

${ }^{c} p C A, F A$, and $T$ molar contents as percentages of total lignin content $(H+G+S=100)$.

The results obtained from the DFRC and DFRC' degradations of the MWLs isolated from rice husks and straw, including the molar yields of the released monomers $\left(\mathrm{H}, \mathrm{G}, \mathrm{G}_{a c}, \mathrm{G}_{p C A}, \mathrm{~S}, \mathrm{~S}_{a c}\right.$, $\mathrm{S}_{p C A}$, and $\left.\mathrm{T}\right)$, as well as the percentages of naturally acetylated guaiacyl $\left(\% \mathrm{G}_{a c}\right)$ and syringyl $\left(\% \mathrm{~S}_{a c}\right)$, and $p$-coumaroylated guaiacyl $\left(\% \mathrm{G}_{p C A}\right)$ and syringyl $\left(\% \mathrm{~S}_{p C A}\right)$ lignin units, are shown in Table 5. The analyses confirmed that $p$-coumarate was the main group acylating the $\gamma-\mathrm{OH}$ of the side-chain in both lignins, and were preferentially attached to the S-lignin units $(30.2 \%$ of total S-units, and only $0.5 \%$ of total G-units were $p$-coumaroylated in the lignin from rice husks, whereas $19.7 \%$ of total S-units, and only $1.2 \%$ of total G-units, were $p$-coumaroylated in the lignin from rice straw). The analysis indicated that acetates were also acylating the $\gamma-\mathrm{OH}$ in these lignins although at a very low level. In the lignin of rice husks, acylation with acetates represented only $0.5 \%$ of all $\mathrm{G}$ units and $0.1 \%$ of all S-units, whereas in the lignin of rice straw, acetates represented $0.4 \%$ of all $\mathrm{G}$ units, and $0.2 \%$ of all S-units. In both cases, acetylation occurred preferentially over G-lignin units. Finally, the DFRC confirmed the occurrence of significant amounts of tricin (T) incorporated into these lignins, being more abundant in the lignin of rice straw (accounting for $8.1 \%$ of all release lignin units), than in the lignin of rice husks (only $1.6 \%$ of all released lignin units), confirming the results obtained from 2D-NMR that indicated the occurrence of higher amounts of tricin incorporated into the lignin of rice straw than into the lignin of rice husks.

\section{DISCUSSION}

In this work, the detailed structural characteristics of the lignins of rice husks (with $22.5 \%$ lignin content) and rice straw (13.5\% lignin content) were thoroughly analyzed by using an array of analytical techniques, including Py-GC/MS, 2D-NMR, and DFRC. The analyses indicated that both lignins were enriched in G-lignin units, and depleted in $\mathrm{H}$ - and S-lignin units, but with noticeable differences in the lignin composition between both tissues. The lignin of rice husks presented a H:G:S composition of 7:81:12 (S/G of 0.15$)$ and was significantly more enriched in G-units than the lignin of rice straw, with a H:G:S composition of 5:71:24 (S/G of 0.34 ). Moreover, these lignins presented a higher content of G-lignin units, and consequently lower S/G ratios, than the lignins of similar tissues in other grasses. Hence, the lignin of rice husks presented a lower $S / G$ ratio than the lignins of barley husks (S/G 0.5) (Rencoret et al., 2015), and more especially than the lignin of corn husks $(S / G \sim 2)$ (del Río et al., 2018). Likewise, the lignin of rice straw presented a lower S/G ratio than the lignins of wheat straw (S/G of 0.5 ) (del Río et al., 2012b), or sugarcane straw (S/G of 0.5) (del Río et al., 2015). The lignin composition greatly influenced the distribution of the different lignin inter-unit linkages in both lignins. As sinapyl alcohol (the precursor of the S-lignin units) presents two methoxyl groups in the aromatic ring, it can only form linkages at the $\beta$-position, being mostly $\beta-O-4$ alkyl aryl ether linkages, and $\beta-\beta$ linkages to a lesser extent; on the contrary, coniferyl alcohol (the precursor of G-lignin units) has only one methoxyl group in the aromatic ring and presents a free position at $\mathrm{C} 5$ to form additional covalent linkages with another lignin unit, such as $\beta-5$ or 5-5 linkages, and producing a more condensed structure. Hence, the lignin from rice husks, that presented a higher abundance of G-lignin units, presented lower levels of $\beta-O-4$ alkyl aryl ether structures (65\% of all measured linkages) and higher levels of condensed structures, particularly phenylcoumarans (23\%), and dibenzodioxocins (5\%). On the other hand, the lignin from rice straw, with a slightly higher $\mathrm{S} / \mathrm{G}$ ratio, presented a higher level of $\beta-O-4$ alkyl aryl ether structures (78\% of all measured linkages), and lower levels of phenylcoumarans (12\%), and dibenzodioxocins (4\%). The analyses, therefore, indicated that the lignins of rice husks and straw have a remarkably more condensed structure than the lignins from similar tissues in related grasses, and that the lignin from rice husks was significantly more condensed than the lignin from rice straw, being therefore more recalcitrant and less prone to chemical and biological degradation. Rice husks are the hard protecting coverings of rice grains, therefore, lignification of rice husks plays an important role in seed protection. The higher recalcitrance of the lignin in rice husks, together with their higher lignin content compared to rice straw, makes this lignin more difficult to degrade, which appears to play a role in protecting the seeds. 


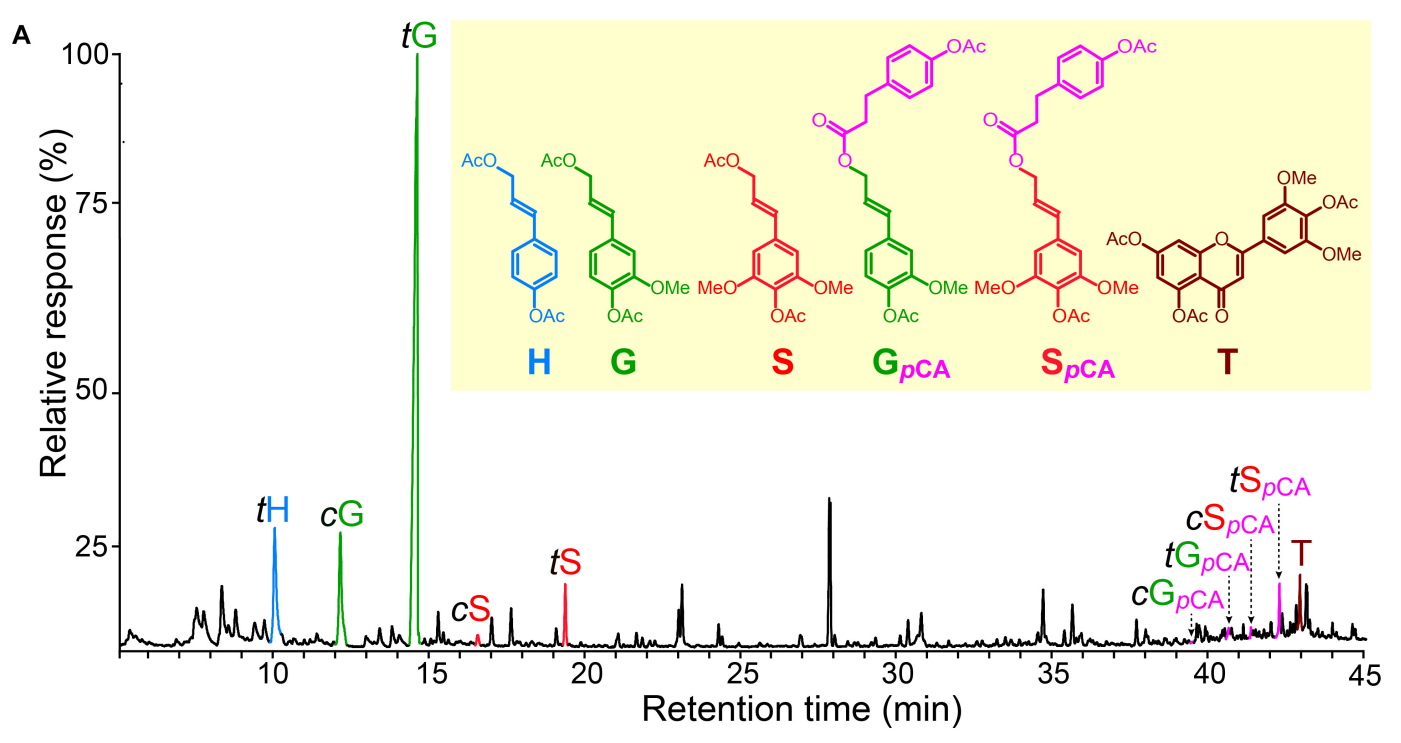

B

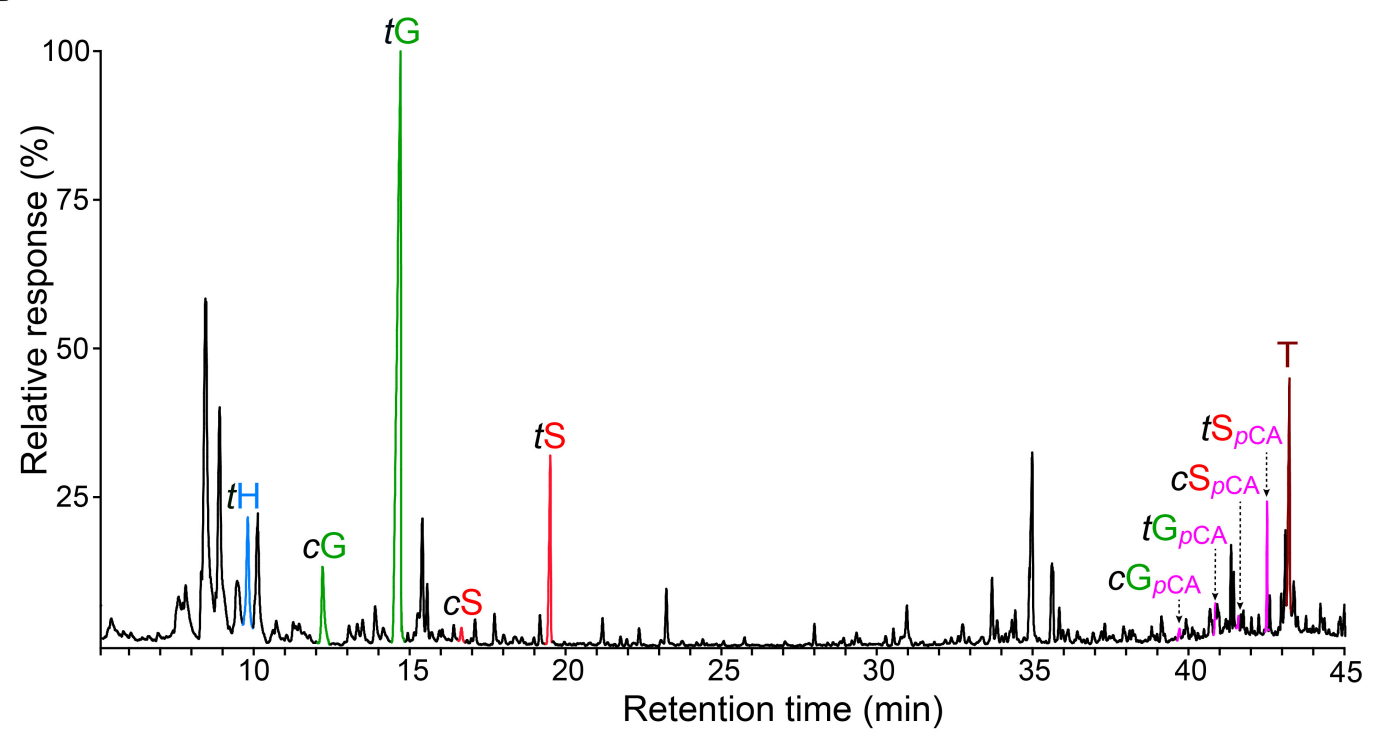

FIGURE 6 | Chromatograms of the DFRC degradation products released from the MWLs isolated from rice husk (A) and rice straw (B) showing the presence of sinapyl (and minor coniferyl) units acylated by $p$-coumarate moieties. $t \mathrm{H}, c \mathrm{G}, t \mathrm{G}, c \mathrm{~S}$, and $t \mathrm{~S}$ are the normal cis- and trans-p-hydroxyphenyl (H), coniferyl $(\mathrm{G})$, and sinapyl (S) alcohol monomers (as their acetate derivates); $c G_{p C A}, t G_{p C A}, c S_{p C A}$, and $t S_{p C A}$ are the cis- and trans-coniferyl and sinapyl dihydro- $p$-coumarates (as their acetate derivatives); $T$ is tricin (as its acetate derivative).

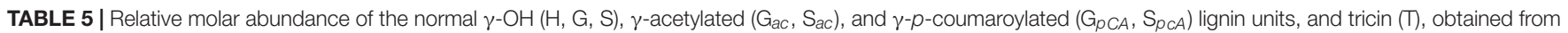
DFRC and DFRC' degradation of the MWLs isolated from rice husks and straw.

\begin{tabular}{|c|c|c|c|c|c|c|c|c|c|c|c|c|}
\hline & H & G & $\mathrm{G}_{a c}$ & $\mathrm{G}_{p c A}$ & $\mathrm{~s}$ & $\mathbf{S}_{a c}$ & $\mathrm{~S}_{p C A}$ & $\mathbf{T}^{a}$ & $\% \mathbf{G}_{a c}{ }^{b}$ & $\% \mathrm{G}_{p c A^{c}}$ & $\% \mathrm{~S}_{a c}{ }^{d}$ & $\% S_{p C A}{ }^{e}$ \\
\hline Rice husks & 10.2 & 83.6 & 0.5 & 0.4 & 3.6 & 0.1 & 1.6 & 1.6 & 0.6 & 0.5 & 1.9 & 30.2 \\
\hline Rice straw & 12.5 & 73.5 & 0.4 & 0.9 & 10.0 & 0.2 & 2.5 & 8.1 & 0.5 & 1.2 & 1.5 & 19.7 \\
\hline
\end{tabular}

The percentages of the different acylated (acetylated and p-coumaroylated) lignin units are also shown.

${ }^{a} T$ molar content referred as to the percentage of total lignin units $\left(H+G+G_{a c}+G_{p C A}+S+S_{a c}+S_{p C A}=100\right)$.

$b \% G_{a c}$ is the percentage of acetylated $G$ units $\left(G_{a c}\right)$ with respect to the total $G$ units $\left(G+G_{a c}+G_{p C A}\right)$.

$c \% G_{p C A}$ is the percentage of $p$-coumaroylated $G$ units $\left(G_{p c A}\right)$ with respect to the total $G$ units $\left(G+G_{a c}+G_{p C A}\right)$.

$d \% S_{a c}$ is the percentage of acetylated $S$ units $\left(S_{a c}\right)$ with respect to the total $S$ units $\left(S+S_{a c}+S_{p c A}\right)$.

e $\% S_{p C A}$ is the percentage of $p$-coumaroylated $S$ units $\left(S_{p C A}\right)$ with respect to the total $S$ units $\left(S+S_{a c}+S_{p C A}\right)$. 
The lignins of rice husks and straw also presented significant amounts of $p$-hydroxycinnamates ( $p$-coumarates and ferulates). Ferulates were found to be mostly attached to the carbohydrates, most likely to the arabinosyl residues of arabinoxylans, as occurred in other grasses, and are known to participate in radical coupling reactions with monolignols that cross-link the carbohydrates to the lignin network (Quideau and Ralph, 1997; Hatfield et al., 2017). On the other hand, $p$-coumarates were found partially acylating the $\gamma-\mathrm{OH}$ of the lignin side-chains (10 and $12 \%$ of all side-chains were $p$-coumaroylated in the lignins of rice husks and straw), and overwhelmingly over S-lignin units, as occurred in other grasses (Grabber et al., 1996; Lu and Ralph, 1999; Hatfield et al., 2008, 2009; Ralph, 2010; del Río et al., 2012a, 2015). The p-coumaroyl-CoA:monolignol transferases involved in the $p$-coumaroylation of the lignin have already been identified and characterized in some grasses and presented higher affinity toward sinapyl alcohol than toward coniferyl alcohol (Withers et al., 2012; Marita et al., 2014; Petrik et al., 2014). However, the role of lignin p-coumaroylation in grasses still remains unclear, although it has been suggested that $p$-coumarates may act as a radical transfer system to help in the radical coupling of sinapyl alcohol into the growing lignin polymer (Hatfield et al., 2008). On the other hand, the lignins from many plants, including grasses, also present acetate groups acylating the $\gamma-\mathrm{OH}$ of the lignin side-chain, and in some cases the acetylation degree occurs to a high extent, as occurred with sisal (78\% acetylation level), kenaf (69\%), or abaca (50\%) (Ralph, 1996; del Río et al., 2007b, 2008). However, the lignins of rice husks and straw were barely acylated with acetate groups at the $\gamma-\mathrm{OH}$; in the lignin from rice husks only $0.5 \%$ of all G-units and $0.1 \%$ of all S-units were acetylated, whereas in the lignin from rice straw, only $0.4 \%$ of all G-units, and $0.2 \%$ of all S-units were acetylated. Interestingly, and contrary to what occurs with $p$-coumarates, in both cases acetylation occurred preferentially over G-lignin units, a feature that has already been observed in the lignins from other grasses, as bamboo, wheat straw, sugarcane, or the pith of elephant grass (del Río et al., 2007b, 2012a,b, 2015). This fact seems to indicate that the acetyl-CoA:monolignol transferases involved in monolignol acetylation in grasses presents a higher affinity toward coniferyl alcohol than toward sinapyl alcohol, contrary to what occurs in most plants where acetylation usually takes place preferentially over S-lignin units (del Río et al., 2007b, 2008). The most important acylated monolignol in the lignins of rice husks and straw was, therefore, sinapyl $p$-coumarate, that accounted for $30.2 \%$ of the total S-units in rice husks, and for $19.7 \%$ of total S-units in rice straw. Sinapyl-p-coumarate has been shown to behave as a true lignin monomer participating in coupling and cross-coupling reactions during lignification, as it was demonstrated by the formation of $\gamma$-acylated $\beta$ $\beta$ tetrahydrofuran structures produced from the $\beta-\beta$ coupling of two $\gamma$-acylated monolignols, or by the cross-coupling of a $\gamma$-acylated and a normal $\gamma-\mathrm{OH}$ monolignol ( $\mathrm{Lu}$ and Ralph, 2005; del Río et al., 2015). The occurrence of the characteristic signals from $\gamma$ - $p$-coumaroylated $\beta-\beta$ tetrahydrofuran structures $\left(\mathbf{C}^{\prime}\right)$ in the HSQC spectrum of the lignin from rice straw clearly evidenced that sinapyl-p-coumarate behaves as a true lignin monomer in these rice tissues participating in coupling reactions during lignification.

Important amounts of the flavone tricin were also found incorporated into the lignin of rice straw $(8.1 \%$ of total lignin units involved in $\beta$-ethers), and to a lesser extent, into the lignin of rice husks (1.6\%). Tricin has mostly been found in the aerial parts of grasses, and therefore, it is likely that the higher amounts of tricin found in rice straw may be related to its potential role as UV-protecting agent, as already suggested (del Río et al., 2020). Tricin was the first phenolic compound from beyond the canonical monolignol biosynthetic pathway that was discovered to behave as a true lignin monomer participating in cross-coupling reactions with traditional monolignols during the lignification process and being integrally incorporated into the lignin polymer (del Río et al., 2012b; Lan et al., 2015). Further studies indicated that tricin was an important component of the lignin of all grasses (del Río et al., 2012b, 2015; Lan et al., 2015, 2016a,b) and that it was also incorporated into the lignins of other monocots, such as in coconut coir (from the Arecaceae), vanilla (from the Orchidaceae), or curaua (from the Bromeliaceae) (Rencoret et al., 2013; Lan et al., 2016b). Due to its particular structure, tricin cannot couple with another tricin molecule and its only possible mode of incorporation into the lignin polymer is through $4-O-\beta$ coupling with a monolignol, and consequently it must always be present at the starting end of a lignin chain; therefore, it seems that tricin may have a role as an initiation site for lignification in grasses (Lan et al., 2015, 2016a). The pathway for tricin biosynthesis in rice has recently been elucidated, and involved the condensation of $p$-coumaroyl-CoA and three malonyl-CoA units catalyzed by Chalcone Synthase (CHS) followed by isomerization by Chalcone Isomerase (CHI) to form the flavanone naringenin, which is then converted to the flavone apigenin by flavone synthase II (FNSII), and further sequential and consecutive hydroxylation and $O$-methylation steps leads to luteolin, chrysoeriol, selgin, and ultimately to tricin, and all the enzymes involved have been identified (Lam et al., $2015,2017)$. The detailed knowledge of the biosynthetic pathway leading to tricin allowed producing genetically engineered rice with altered lignins that resulted in the incorporation of other flavonoids, such as the flavanone naringenin or the flavone apigenin into their structure, instead of tricin (Lam et al., 2017, 2019). Tricin can also occur in grasses in the form of extractives, such as free tricin, as O-glucosides, as flavonolignans, or as flavonolignan glucosides. A detailed quantitative study of the tricin content in several grasses demonstrated that the content of tricin incorporated into the lignin polymer was much higher than the content of extractable tricin (Lan et al., 2016b, 2019). In the case of rice straw, the content of tricin incorporated into the lignin amounted up to $980 \mathrm{mg} / \mathrm{kg}$ in comparison to only $195 \mathrm{mg} / \mathrm{kg}$ of extractable tricin (Lan et al., 2016b), which indicates that the lignin of rice straw could be an attractive and potential source for the extraction of this valuable compound. It is important to note that tricin presents multiple nutraceutical and pharmacological applications, and has a potential role as a chemopreventive and anticancer agent (Jian-Min and Ragai, 2010). The fact that tricin is linked to the lignin network exclusively by labile and easily cleaved $\beta$-ether bonds adds to the 
feasibility of considering rice straw lignin as a potential feedstock for obtaining valuable tricin.

In general terms, the detailed chemical and structural characteristics of the lignins of rice husks and rice straw provided in this work will be of great help for tailoring appropriate and efficient conversion technologies for these lignocellulosic materials as well as for developing lignin-based high value added products. Fractionation of rice by-products into their cell wall components (cellulose, hemicelluloses, and lignin) is a main step for their efficient utilization in integrated biorefineries and to maximize their value-added conversion into biofuels and chemicals. Various pretreatment techniques have been used for this purpose, including chemical (acid, alkaline, and oxidation) and thermochemical (steam explosion, autohydrolysis, and organosolv) methods, or combinations of them (Imman et al., 2015; Abraham et al., 2016; Singh and Dhepe, 2016; Wood et al., 2016; Wu et al., 2018; Swain et al., 2019; Takeda et al., 2019; Sharma et al., 2020). However, fractionation of cell wall components is greatly influenced by the lignin characteristics. As shown above, the lignins of rice husks and rice straw are highly recalcitrant and difficult to depolymerize, and it can be anticipated that severe and harsh conditions must be necessary to achieve delignification in order to access the carbohydrates. In particular, the data indicated that rice husks exhibited a much higher degree of recalcitrance compared to rice straw as a result of the higher lignin content and the higher degree of condensed linkages in this lignin. This explains the large differences observed in the degree of delignification between both materials reported in previous works (Wood et al., 2016; Wu et al., 2018); for example, and despite having a similar carbohydrate content, rice husks were found to be much less susceptible to saccharification by steam explosion, even under optimal pretreatments conditions, compared to rice straw (Wood et al., 2016). The results of this work indicate that the use of rice husks as raw material for biorefinery purposes would be difficult to achieve and that its potential exploitation will require severe conditions to cope with its recalcitrance. New developments in pretreatment technologies or breeding strategies to reduce the recalcitrance of rice husks have been suggested to address this problem (Wood et al., 2016).

On the other hand, the potential applications of the lignins extracted from the rice by-products will be determined by the lignin composition. Hence, the lignins from rice husks and rice straw are highly enriched in G-units and are suitable for producing phenols with unsubstituted C5 positions, which would provide the necessary reactivity to produce phenol formaldehyde (PF) resins, and therefore, could be appropriate for this type of application (de Menezes et al., 2017). Furthermore, these lignins can also produce significant amounts of non-methoxylated $p$-hydroxyphenyl units arising from the $p$-coumarate groups attached to the lignin side chains that could also provide reactivity

\section{REFERENCES}

Abraham, A., Mathew, A. K., Sindhu, R., Pandey, A., and Binod, P. (2016). Potential of rice straw for bio-refining: an overview. Bioresour. Technol. 215, 29-36. doi: 10.1016/j.biortech.2016.04.011 for PF resin applications. However, it is important to note that the pretreatment procedures used to extract the lignins will also have a great impact on the structure, purity and physicochemical properties of the recovered lignins and, hence, on their subsequent applications.

Finally, and perhaps more importantly, the results of this study indicate that these lignins also contain significant amounts of $p$-hydroxycinnamic acids, as well as the flavonoid tricin, which can be recovered as different side streams. The core lignin of these rice by-products is mostly composed of G-units, making them highly recalcitrant and difficult to degrade. However, as shown above, $p$-coumarates are esterified to the $\gamma$-OH of the lignin side chain, and can be easily released by mild alkaline treatment; likewise, tricin is linked exclusively by $\beta$-ether bonds, which can also be easily cleaved releasing this valuable flavonoid. Therefore, rice husks and rice straw may represent a promising source for these fine chemicals in the context of a lignocellulosic biorefinery.

\section{DATA AVAILABILITY STATEMENT}

The raw data supporting the conclusions of this article will be made available by the authors, without undue reservation.

\section{AUTHOR CONTRIBUTIONS}

MJR, GM, AG, and JR made the experimental work. JCR designed the work and wrote the article, with contributions from the rest of authors. All authors approved the version submitted.

\section{FUNDING}

This study has been funded by the Spanish Project AGL201783036-R (financed by Agencia Estatal de Investigación, AEI, and Fondo Europeo de Desarrollo Regional, FEDER). MJR thanks the Spanish Ministry of Science, Innovation and Universities for a FPI fellowship (PRE2018-083267). We acknowledge support of the publication fee by the CSIC Open Access Publication Support Initiative through its Unit of Information Resources for Research (URICI).

\section{ACKNOWLEDGMENTS}

The authors thank Bernardo Hermosín (IRNAS-CSIC) for providing the samples of rice husks and straw. The authors also thank Manuel Angulo for performing the NMR analyses that were obtained on a Bruker Avance III $500 \mathrm{MHz}$ instrument from the NMR facilities of the General Research Services of the University of Seville (SGI-CITIUS). 
Björkman, A. (1956). Studies on finely divided wood. Part 1. Extraction of lignin with neutral solvents. Sven. Papperstidn. 59, 477-485.

Bocchini, P., Galletti, G. C., Camarero, S., and Martínez, A. T. (1997). Absolute quantitation of lignin pyrolysis products using an internal standard. J. Chromatogr. A 773, 227-232. doi: 10.1016/S0021-9673(97)00114-3

Browning, B. L. (1967). Methods of Wood Chemistry, Vol. II. (New York, NY: Wiley-Interscience Publishers), 498.

Campbell, M. M., and Sederoff, R. R. (1996). Variation in lignin content and composition. Plant Physiol. 110, 3-13. doi: 10.1104/pp.110.1.3

Chandrasekhar, S., Satyanarayana, K. G., Pramada, P. N., Raghavan, P., and Gupta, T. N. (2003). Processing, properties and applications of reactive silica from rice husk - An overview. J. Mat. Sci. 38, 3159-3168. doi: 10.1023/A:1025157114800

Dagnino, E. P., Felissia, F. E., Chamorro, E., and Area, M. C. (2018). Studies on lignin extraction from rice husk by a soda-ethanol treatment: kinetics, separation and characterization products. Chem. Eng. Res. Des. 129, 209-216. doi: 10.1016/j.cherd.2017.10.026

Darwill, A., McNeil, M., Albersheim, P., and Delmer, D. (1980). "The primary cell-walls of flowering plants," in The Biochemistry of Plants: A Comprehensive Treatise, ed. N. Tolbert (New York, NY: Academic Press), 91-162. doi: 10.1016/ b978-0-12-675401-8.50009-9

del Río, J. C., González-Vila, F. J., and Martín, F. (1996). Thermally assisted hydrolysis and alkylation as a novel pyrolytic approach for the structural characterization of natural biopolymers and geomacromolecules. Trends Anal. Chem. 15, 70-79. doi: 10.1016/0165-9936(96)80763-1

del Río, J. C., Gutiérrez, A., Rodríguez, I. M., Ibarra, D., and Martínez, A. T. (2007a). Composition of non-woody plant lignins and cinnamic acids by PyGC/MS, Py/TMAH and FT-IR. J. Anal. Appl. Pyrol. 79, 39-46. doi: 10.1016/j. jaap.2006.09.003

del Río, J. C., Marques, G., Rencoret, J., Martínez, A. T., and Gutiérrez, A. (2007b). Occurrence of naturally acetylated lignin units. J. Agric. Food Chem. 55, 5461-5468. doi: 10.1021/jf0705264

del Río, J. C., Lino, A. G., Colodette, J. L., Lima, C. F., Gutiérrez, A., Martínez, A. T., et al. (2015). Differences in the chemical structure of the lignins from sugarcane bagasse and straw. Biomass Bioenerg. 81, 322-338. doi: 10.1016/j. biombioe.2015.07.006

del Río, J. C., Prinsen, P., Rencoret, J., Nieto, L., Jiménez-Barbero, J., Ralph, J., et al. (2012a). Structural characterization of the lignin in the cortex and pith of elephant grass (Pennisetum purpureum) stems. J. Agric. Food Chem. 60, 3619-3634. doi: 10.1021/jf300099g

del Río, J. C., Rencoret, J., Prinsen, P., Martínez, Á. T., Ralph, J., and Gutiérrez, A. (2012b). Structural characterization of wheat straw lignin as revealed by analytical pyrolysis, 2D-NMR, and reductive cleavage methods. J. Agric. Food Chem. 60, 5922-5935. doi: 10.1021/jf301002n

del Río, J. C., Rencoret, J., Gutiérrez, A., Elder, T., Kim, H., and Ralph, J. (2020). Lignin monomers from beyond the canonical monolignol biosynthetic pathway - Another brick in the wall. ACS Sustain. Chem. Eng. 8, 4997-5012. doi: 10.1021/acssuschemeng.0c01109

del Río, J. C., Rencoret, J., Gutiérrez, A., Kim, H., and Ralph, J. (2017). Hydroxystilbenes are monomers in palm fruit endocarp lignins. Plant Physiol. 174, 2072-2082. doi: 10.1104/pp.17.00362

del Río, J. C., Rencoret, J., Gutiérrez, A., Kim, H., and Ralph, J. (2018). Structural characterization of lignin from maize (Zea mays L.) fibers: evidence for diferuloylputrescine incorporated into the lignin polymer in maize kernels. J. Agric. Food Chem. 66, 4402-4413. doi: 10.1021/acs.jafc.8b00880

del Río, J. C., Rencoret, J., Marques, G., Gutiérrez, A., Ibarra, D., Santos, J. I., et al. (2008). Highly acylated (acetylated and/or p-coumaroylated) native lignins from diverse herbaceous plants. J. Agric. Food Chem. 56, 9525-9534. doi: 10. 1021/jf800806h

de Menezes, F. F., Rencoret, J., Nakanishi, S. C., Nascimento, V. M., Silva, V. F. N., Gutiérrez, A., et al. (2017). Alkaline pretreatment severity leads to different lignin applications in sugar cane biorefineries. ACS Sustain. Chem. Eng. 5, 5702-5712. doi: 10.1021/acssuschemeng.7b00265

Donaldson, L. A. (2001). Lignification and lignin topochemistry - an ultrastructure view. Phytochemistry 57, 859-873. doi: 10.1016/S00319422(01)00 049-8

FAOSTAT (2020). Food and Agriculture Organization of the United Nations. Available online at: http://faostat3.fao.org (accessed November 4, 2020).
Gao, Y., Guo, X., Liu, Y., Fang, Z., Zhang, R., You, L., et al. (2018). A full utilization of rice husk to evaluate phytochemical bioactivities and prepare cellulose nanocrystals. Sci. Rep. 8:10482. doi: 10.1038/s41598-018-27635-3

Gou, G., Wei, W., Jiang, M., Zhang, S., Tingju, L., Xie, X., et al. (2018). "Environmentally friendly method for the separation of cellulose from steamexploded rice straw and its high-value applications," in Pulp and Paper Processing, ed. S. N. Kazi (London: IntechOpen), 133-154. doi: 10.5772/ intechopen.79014

Grabber, J. H., Quideau, S., and Ralph, J. (1996). p-Coumaroylated syringyl units in maize lignin: implications for $\beta$-ether cleavage by thioacidolysis. Phytochemistry 43, 1189-1194. doi: 10.1016/S0031-9422(96)00431-1

Hatfield, R., Ralph, J., and Grabber, J. H. (2008). A potential role for sinapyl $p$-coumarate as a radical transfer mechanism in grass lignin formation. Planta 228, 919-928. doi: 10.1007/s00425-008-0791-4

Hatfield, R. D., Marita, J. M., Frost, K., Grabber, J., Ralph, J., Lu, F., et al. (2009). Grass lignin acylation: p-coumaroyl transferase activity and cell wall characteristics of C3 and C4 grasses. Planta 229, 1253-1267. doi: 10.1007/ s00425-009-0900-z

Hatfield, R. D., Rancour, D. M., and Marita, J. M. (2017). Grass cell walls: a story of cross-linking. Front. Plant Sci. 7:2056. doi: 10.3389/fpls.2016.02056

Imman, S., Arnthong, J., Burapatana, V., Champreda, V., and Laosiripojana, N. (2015). Fractionation of rice straw by a single-step solvothermal process: effects of solvents, acid promoters, and microwave treatment. Renew. Energy 83, 663-673. doi: 10.1016/j.renene.2015.04.062

Jian-Min, Z., and Ragai, I. (2010). Tricin-a potential multifunctional nutraceutical. Phytochem. Rev. 9, 413-424. doi: 10.1007/s11101-009-9161-5

Kalita, E., Narth, B. K., Deb, P., Agan, F., Islam, M. R., and Saikia, K. (2015). High quality fluorescent cellulose nanofibers from endemic rice husk: isolation and characterization. Carbohydr. Polym. 122, 308-313. doi: 10.1016/j.carbpol.2014. 12.075

Kim, H., Ralph, J., and Akiyama, T. (2008). Solution-state 2D NMR of ball-milled plant cell-wall gels in DMSO- $d_{6}$. Bioenergy Res. 1, 56-66. doi: 10.1007/s12155008-9004-z

Kumar, A. K., Parikh, B. S., and Pravakar, M. (2016). Natural deep eutectic solvent mediated pretreatment of rice straw: bioanalytical characterization of lignin extract and enzymatic hydrolysis of pretreated biomass residue. Environ. Sci. Pollut. Res. 23, 9265-9275. doi: 10.1007/s11356-015-4780-4

Kumar, M., Upadhyay, S. N., and Mishra, P. K. (2019). A comparative study of thermochemical characteristics of lignocellulosic biomasses. Bioresour. Technol. Rep. 8:100186. doi: 10.1016/j.biteb.2019.100186

Lam, P. Y., Liu, H., and Lo, C. (2015). Completion of tricin biosynthesis pathway in rice: cytochrome P450 75B4 is a unique chrysoeriol 5'-hydroxylase. Plant Physiol. 168, 1527-1536. doi: 10.1104/pp.15.00566

Lam, P. Y., Tobimatsu, Y., Matsumoto, N., Suzuki, S., Lan, W., Takeda, Y., et al. (2019). OsCAldOMT1 is a bifunctional $O$-methyltransferase involved in the biosynthesis of tricin-lignins in rice cell walls. Sci. Rep. 9:11597. doi: 10.1038/ s41598-019-47957-0

Lam, P. Y., Tobimatsu, Y., Takeda, Y., Suzuki, S., Yamamura, M., Umezawa, T., et al. (2017). Disrupting flavone synthase II alters lignin and improves biomass digestibility. Plant Physiol. 174, 972-985. doi: 10.1104/pp.16.01973

Lan, W., Lu, F., Regner, M., Zhu, Y., Rencoret, J., Ralph, S. A., et al. (2015). Tricin, a flavonoid monomer in monocot lignification. Plant Physiol. 167, 1284-1295. doi: 10.1104/pp.114.253757

Lan, W., Morreel, K., Lu, F., Rencoret, J., del Río, J. C., Vooren, W., et al. (2016a). Maize tricin-oligolignol metabolites and their implications for monocot lignification. Plant Physiol. 171, 810-820. doi: 10.1104/pp.16.02012

Lan, W., Rencoret, J., Lu, F., Karlen, S. D., Smith, B. G., Harris, P. J., et al. (2016b). Tricin-lignins: occurrence and quantitation of tricin in relation to phylogeny. Plant J. 88, 1046-1057. doi: 10.1111/tpj.13315

Lan, W., Rencoret, J., del Río, J. C., and Ralph, J. (2019). “Tricin in grass lignin: biosynthesis, characterization, and quantitation," in Lignin: Biosynthesis, Functions and Economic Significance, eds F. Lu and F. Yue (New York, NY: Nova Science Publishers, Inc), 51-78.

Lourenço, A., Rencoret, J., Chematova, C., Gominho, J., Gutiérrez, A., del Río, J. C., et al. (2016). Lignin composition and structure differs between xylem, phloem and phellem in Quercus suber L. Front. Plant Sci. 7:1612. doi: 10.3389/fpls.2016. 01612 
Lu, F., and Ralph, J. (1997a). Derivatization followed by reductive cleavage (DFRC method), a new method for lignin analysis: protocol for analysis of DFRC monomers. J. Agric. Food Chem. 45, 2590-2592. doi: 10.1021/jf970258h

Lu, F., and Ralph, J. (1997b). The DFRC method for lignin analysis. 1. New method for $\beta$-aryl ether cleavage: lignin model studies. J. Agric. Food Chem. 45, 4655-4660. doi: 10.1021/j9970539p

Lu, F., and Ralph, J. (1998). The DFRC method for lignin analysis. 2. Monomers from isolated lignin. J. Agric. Food Chem. 46, 547-552. doi: 10.1021/jf970676m

Lu, F., and Ralph, J. (1999). Detection and determination of $p$-coumaroylated units in lignins. J. Agric Food Chem. 47, 1988-1992. doi: 10.1021/jf981140j

Lu, F., and Ralph, J. (2005). Novel $\beta-\beta$ Structures in lignins incorporating acylated monolignols. Appita 233-237.

Lu, P., and Hsieh, Y. L. (2012). Preparation and characterization of cellulose nanocrystals from rice straw. Carbohydr. Polym. 87, 564-573. doi: 10.1016/j. carbpol.2011.08.022

Marita, J. M., Hatfield, R. D., Rancour, D. M., and Frost, K. E. (2014). Identification and suppression of the $p$-coumaroyl CoA:hydroxycinnamyl alcohol transferase in Zea mays L. Plant J. 78, 850-864. doi: 10.1111/tpj.12510

Petrik, D., Karlen, S. D., Cass, C., Padmakshan, D., Lu, F., Liu, S., et al. (2014). p-Coumaroyl-CoA:monolignol transferase (PMT) acts specifically in the lignin biosynthetic pathway in Brachypodium distachyon. Plant J. 77, 713-726. doi: $10.1111 /$ tpj. 12420

Quideau, S., and Ralph, J. (1997). Lignin-ferulate cross-links in grasses. Part 4. Incorporation of 5-5-coupled diferulate into lignin. J. Chem. Soc. Perkin Trans. 1, 2351-2358. doi: 10.1039/A701808h

Ralph, J. (1996). An unusual lignin from kenaf. J. Nat. Prod. 59, 341-342. doi: $10.1021 / \mathrm{np} 960143 \mathrm{~s}$

Ralph, J. (2010). Hydroxycinnamates in lignification. Phytochem. Rev. 9, 65-83. doi: 10.1007/s11101-009-9141-9

Ralph, J., and Hatfield, R. D. (1991). Pyrolysis-GC/MS characterization of forage materials. J. Agric. Food Chem. 39, 1426-1437. doi: 10.1021/jf00008a014

Ralph, J., and Lu, F. (1998). The DRC method for lignin analysis. 6. A simple modification for identifying natural acetates in lignin. J. Agric. Food Chem. 46, 4616-4619. doi: 10.1021/jf980680d

Ralph, J., Lundquist, J., Brunow, G., Lu, F., Kim, H., Schatz, P. F., et al. (2004). Lignins: natural polymers from oxidative coupling of 4hydroxyphenylpropanoids. Phytochem. Rev. 3, 29-60. doi: 10.1023/b:phyt. 0000047809.65444.a4

Ralph, S. A., Ralph, J., and Landucci, L. (2009). NMR Database of lignin and Cell Wall Model Compounds. Available online at: https://www.glbrc.org/databases_ and_software/nmrdatabase/NMR_DataBase_2009_Complete.pdf (accessed April, 2020).

Rencoret, J., Gutiérrez, A., Nieto, L., Jiménez-Barbero, J., Faulds, C. B., Kim, H., et al. (2011). Lignin composition and structure in young versus adult Eucalyptus globulus plants. Plant Physiol. 155, 667-682. doi: 10.1104/pp.110.16 7254

Rencoret, J., Kim, H., Anderson, B. E., Gutiérrez, A., Ralph, J., and del Río, J. C. (2018). Variability in lignin composition and structure in cell walls of different parts of macaúba (Acrocomia aculeata) palm fruit. J. Agric. Food Chem. 66, 138-153. doi: 10.1021/acs.jafc.7b04638

Rencoret, J., Marques, G., Gutiérrez, A., Nieto, L., Santos, J. I., Jiménez-Barbero, J., et al. (2009). HSQC-NMR analysis of lignin in woody (Eucalyptus globulus and Picea abies) and non-woody (Agave sisalana) ball-milled plant materials at the gel state. Holzforschung 63, 691-698. doi: 10.1515/HF.2009.070

Rencoret, J., Prinsen, P., Gutiérrez, A., Martínez, A. T., and del Río, J. C. (2015). Isolation and structural characterization of the milled wood lignin, dioxane lignin, and cellulolytic lignin preparations from brewer's spent grain. J. Agric. Food Chem. 63, 603-613. doi: 10.1021/jf505808c
Rencoret, J., Ralph, J., Marques, G., Gutiérrez, A., Martínez, A. T., and del Río, J. C. (2013). Structural characterization of lignin isolated from coconut (Cocos nucifera) coir fibers. J. Agric. Food Chem. 61, 2434-2445. doi: 10.1021/jf304686x

Salanti, A., Zoia, L., Orlandi, M., Zanini, F., and Elegir, G. (2010). Structural characterization and antioxidant activity evaluation of lignin from rice husk. J. Agric. Food Chem. 58, 10049-10055. doi: 10.1021/jf10 $2188 \mathrm{k}$

Sharma, A., Singh, G., and Arya, S. K. (2020). Biofuel from rice straw. J. Clean. Prod. 277:124101. doi: 10.1016/j.jclepro.2020.124101

Singh, S. K., and Dhepe, P. L. (2016). Isolation of lignin by organosolv process from different varieties of rice husk: understanding their physical and chemical properties. Bioresour. Technol. 221, 310-317. doi: 10.1016/j.biortech.2016.09. 042

Swain, M. R., Singh, A., Sharma, A. K., and Tuli, D. K. (2019). "Bioethanol production from rice- and wheat straw: an overview," in Bioethanol Production from Food Crops: Sustainable Sources, Interventions and Challenges, eds R. C. Ray and S. Ramachandran (London: Academic Press), 213-231. doi: 10.1016/ B978-0-12-813766-6.00011-4

Takeda, Y., Tobimatsu, Y., Yamamura, M., Takano, T., Sakamoto, M., and Umezawa, T. (2019). Comparative evaluations of lignocellulose reactivity and usability in transgenic rice plants with altered lignin composition. J. Wood Sci. 65:6. doi: 10.1186/s10086-019-1784-6

Tappi Standard Test Methods 2004-2005 (2004). Tappi Test Methods. Atlanta, GA: Tappi Press.

Vanholme, R., De Meester, B., Ralph, J., and Boerjan, W. (2019). Lignin biosynthesis and its integration into metabolism. Curr. Opin. Biotechnol. 56, 230-239. doi: 10.1016/j.copbio.2019.02.018

Vanholme, R., Demedts, B., Morreel, K., Ralph, J., and Boerjan, W. (2010). Lignin biosynthesis and structure. Plant Physiol. 152, 895-905. doi: 10.1104/pp.110. 155119

Vermerris, W., and Boon, J. J. (2001). Tissue specific patterns of lignification are disturbed in the brown midrib2 mutant of maize (Zea mays L.). J. Agric. Food Chem. 49, 721-728. doi: 10.1021/jf000740r

Withers, S., Lu, F., Kim, H., Zhu, Y., Ralph, J., and Wilkerson, C. G. (2012). Identification of a grass-specific enzyme that acylates monolignols with p-coumarate. J. Biol. Chem. 287, 8347-8355. doi: 10.1074/jbc.M111.284497

Wood, I. P., Cao, H.-G., Tran, L., Cook, N., Ryden, P., Wilson, D. R., et al. (2016). Comparison of saccharification and fermentation of steam exploded rice straw and rice husk. Biotechnol. Biofuels 9:193. doi: 10.1186/s13068-016-0599-6

Wu, J., Collins, S. R. A., Elliston, A., Wellner, N., Dicks, J., Roberts, I. N., et al. (2018). Release of cell wall phenolic esters during hydrothermal pretreatment of rice husks and rice straw. Biotechnol. Biofuels 11:162. doi: 10.1186/s13068018-1157-1

Yeframova, S., Zharmenov, A., Sukharnikov, Y., Bunchuk, L., Kablanbekov, A., Anarbekov, K., et al. (2019). Rice husk hydrolytic lignin transformation in carbonization process. Molecules 24:3075. doi: 10.3390/molecules 24173075

Conflict of Interest: The authors declare that the research was conducted in the absence of any commercial or financial relationships that could be construed as a potential conflict of interest.

Copyright ( 2021 Rosado, Rencoret, Marques, Gutiérrez and del Río. This is an open-access article distributed under the terms of the Creative Commons Attribution License (CC BY). The use, distribution or reproduction in other forums is permitted, provided the original author(s) and the copyright owner(s) are credited and that the original publication in this journal is cited, in accordance with accepted academic practice. No use, distribution or reproduction is permitted which does not comply with these terms. 